\title{
High-resolution stalagmite stratigraphy supports the Late Holocene tephrochronology of southernmost Patagonia
}

\author{
Björn Klaes ( $\sim$ klaesb@uni-trier.de ) \\ Trier University https://orcid.org/0000-0002-9068-0278 \\ Gerhard Wörner \\ University of Göttingen https://orcid.org/0000-0003-1110-8976

\section{Katrina Kremer}

ETH

\section{Klaus Simon}

Georg-August-University Göttingen

\section{Denis Scholz}

University of Mainz

\section{Carsten Mueller}

University of Copenhagen https://orcid.org/0000-0003-4119-0544

\section{Carmen Hoschen}

TU München https://orcid.org/0000-0001-5774-2062

Julian Struck

Friedrich-Schiller-University Jena https://orcid.org/0000-0001-6102-7547

\section{Helge Arz}

Leibniz Institute for Baltic Sea Research https://orcid.org/0000-0002-1997-1718

\section{Sören Thiele-Bruhn}

Trier University

\section{Daniel Schimpf}

Trier University

\section{Rolf Kilian}

Universität Trier

\section{Article}

Keywords: tephrostratigraphy, volcanic ash, tephra, volcanism, Southern Andes, non-karst, speleothem, dating 
DOI: https://doi.org/10.21203/rs.3.rs-350595/v1

License: (c) (1) This work is licensed under a Creative Commons Attribution 4.0 International License. Read Full License

Version of Record: A version of this preprint was published at Communications Earth \& Environment on February 10th, 2022. See the published version at https://doi.org/10.1038/s43247-022-00358-0. 


\section{High-resolution stalagmite stratigraphy supports the Late Holocene tephrochronology of southernmost Patagonia}

\section{Björn Klaes ${ }^{1,2 *}$, Gerhard Wörner ${ }^{3}$, Katrina Kremer ${ }^{4}$, Klaus Simon ${ }^{3}$, Denis Scholz ${ }^{5}$ Carsten W.} Mueller $^{6}$, Carmen Höschen ${ }^{7}$, Julian Struck ${ }^{8}$, Helge Wolfgang Arz', Sören Thiele-Bruhn², Daniel

\section{Schimpf ${ }^{1}$, Rolf Kilian ${ }^{1,10 \dagger}$}

${ }^{1}$ Geology Department, Trier University, Campus II (Geozentrum), Behringstraße 21, D-54296 Trier, Germany; *klaesb@uni-trier.de,d_schimpf@gmx.de

${ }^{2}$ Soil Science Department, Trier University, Campus II (Geozentrum), Behringstraße 21, D-54296 Trier, Germany; thiele@uni-trier.de

${ }^{3}$ Division of Geochemistry and Isotope Geology, GZG, Georg-August-University Göttingen, Goldschmidtstraße 1, D-37077 Göttingen, Germany; gwoerne@gwdg.de, ksimon@gwdg.de

${ }^{4}$ Swiss Seismological Service, ETH Zürich, Sonneggstrasse 5, CH-8092 Zürich, Switzerland, katrina.kremer@sed.ethz.ch

${ }^{5}$ Institute for Geosciences, Johannes Gutenberg University Mainz, Johann-Joachim-Becher-Weg 21, D55128 Mainz, Germany; scholzd@uni-mainz.de

${ }^{6}$ Department for Geosciences and Environmental Management, University of Copenhagen, Øster Voldgade 10, DK-1350 København K, Denmark; cm@ign.ku.dk

${ }^{7}$ Soil Science, Research Department Life Science Systems, TUM School of Life Sciences, Technical University of Munich, Emil-Ramann-Straße 2, D-85354 Freising-Weihenstephan, Germany; carmen.hoeschen@wzw.tum.de

${ }^{8}$ Department of Physical Geography, Friedrich-Schiller-University Jena, Löbdergraben 32, D-07743 Jena, Germany; julian.struck@uni-jena.de

${ }^{9}$ Marine Geology Section, Leibniz Institute for Baltic Sea Research Warnemünde (IOW), Seestraße 15, D-18119 Rostock, Germany; helge.arz@io-warnemuende.de

\section{${ }^{10}$ University of Magallanes, Avenida Bulnes 01855, Punta Arenas, Chile}

8 * corresponding author (B. Klaes);

$$
\dagger=\text { deceased }
$$



speleothem, dating

Abstract

Volcanic ash layers are important markers for the chronostratigraphy of paleoclimate and paleoenvironmental archives at the southern tip of South America. However, this requires that tephras are well-dated. We report geochemical data from the MA1 stalagmite formed in a non-karst cave near Mt. Burney volcano in southernmost Patagonia $\left(\sim 53^{\circ} \mathrm{S}\right)$. High-resolution LA-ICP-MS analyses, SEM imagery, and NanoSIMS enable to identify volcanogenic signals during the last $4.5 \mathrm{kyrs}$ BP from subannual trace element variations and tephra particles in distinct laminae. The new ${ }^{230} \mathrm{Th} / \mathrm{U}$-chronology of MA1 provides precise dating of tephra from Mt. Burney (MB) and Aguilera (A) at $4216^{+93} /-193$ yrs BP $\left(\mathrm{MB}_{2}\right), 2291 \pm 33$ yrs BP $\left(\mathrm{MB}_{3}\right), 853^{+41} /-60$ yrs BP $\left(\mathrm{MB}_{4}\right)$ and $2978^{+91} /-104$ yrs BP $\left(\mathrm{A}_{1}\right)$. This unique high-resolution record of MA1 holds potential to date further eruptions from Southern Andean volcanoes for the tephrochronology in this critical region, and potentially also large-volume explosive volcanism off South America.

Introduction

Severe and long-lasting impact on regional ecosystems from explosive volcanic eruptions and ash (tephra) fallout has been observed in fragile environments such as the super-humid South Patagonian Andes ${ }^{1,2}$. While geochemical fingerprinting links tephra glass shard compositions to their volcanic source and represents a valuable tool in tephrochronology ${ }^{3}$, the dating of distinct tephra layers enables a reconstruction of the regional history of volcanic activity and provides isochronous marker horizons for stratigraphic interpretations and correlation of paleoenvironmental archives over large geographical areas $^{4}$. Despite intensive research and rapid advances in the development of tephrochronological methods in the last few decades, the accurate identification of distinct tephra layers and the precise synchronization of single volcanic events recorded in geological archives from different depositional environments remains challenging ${ }^{4,5}$.

Accurate age constraints are particularly difficult for sedimentary archives in southernmost Patagonia. There, the ages of widespread Holocene tephra layers from Plinian eruptions from volcanoes of the Patagonian Andes ${ }^{6}$ in the southern segment of the Southern $\left(41.5-46^{\circ} \mathrm{S}\right)$ and the Austral $\left(49-55^{\circ} \mathrm{S}\right)$ Volcanic Zones were mainly deduced from ${ }^{14} \mathrm{C}$-dated materials of terrestrial outcrops, peat and marine/lacustrine sediment cores $^{3,5,7,8}$. This tephrochronological framework constitutes a principal reference for the stratigraphy of most geological records used in paleoclimate/paleoenvironmental 
Age uncertainties and problems with correlation of tephra layers in regional soils and sediment or peat core archives are due to variable composition, unclear stratigraphy and diverging chronologies based on ${ }^{14} \mathrm{C}$-dated carbonates, bulk organic matter $(\mathrm{OM})$ or single plant remains ${ }^{3,4}$. In particular, ${ }^{14} \mathrm{C}$-dated components of soils and sediments can have age offsets of hundreds of years due to reservoir effects caused by, e.g., the re-sedimentation and bioturbation of older OM or carbonate dissolution ${ }^{\mathbf{1 0 , 1 1}}$, which have serious implications for age models. Large errors in age determination of volcanic ash layers also occur from interpolation of bracketing ${ }^{14} \mathrm{C}_{-}$dates $^{4}$ and/or age constraints based on estimated sedimentation/peat accumulation rates ${ }^{12,13}$.

Further challenges include the correct identification of the source volcano by the characteristic physical/textural properties as well as the mineralogical and geochemical composition of tephra pumice and glass shards ${ }^{8}$. Site-dependent, potentially intense weathering processes in acidic peatland ecosystems ${ }^{14}$ can compromise geochemical fingerprinting methods for tephra correlation ${ }^{3}$. Chemical weathering over long periods strongly alters the composition of volcanic glass and embedded phenocrysts, leading to drastic changes of major and trace element concentrations ${ }^{15,16,17}$.

Albeit their increasingly important role as high-resolution terrestrial archives for the reconstruction of past climate variations and environmental changes, only few speleothem records have so far contributed to regional tephrochronologies worldwide ${ }^{18,19,20,21,22}$. This is due to the fact that an unequivocal detection of volcanic signals in speleothems is difficult and speleothems containing distinct layers with tephra glass shards or even small pumice particles have - to our knowledge - not yet been documented.

However, speleothems can be very useful for such studies because ${ }^{230} \mathrm{Th} / \mathrm{U}$-dating allows exceptionally accurate and precise dating and variations in chemical elements can be detected with up to (sub-) annual resolution. Therefore, speleothems have great potential for high precision dating of volcanic events comparable to ice core tephra records ${ }^{18,23}$. Combined with stable isotope data $\left(\delta^{18} \mathrm{O}, \delta^{13} \mathrm{C}\right)$ and other trace element proxies, speleothem records enable both the dating of volcanic activity and the evaluation of possible environmental and climate impacts following from the documented eruptions ${ }^{18,19,20,21}$.

In this work, we analyze a non-karst speleothem (MA1 stalagmite ${ }^{24}$ ) to better constrain the Late Holocene tephrostratigraphy in Southern Patagonia and provide evidence for soil-environmental changes related to tephra deposition under extreme climate conditions. This speleothem formed in a small cave ca. $40 \mathrm{~km} \mathrm{~S}$ of Mt. Burney volcano and recorded sub-annual trace element variations detected by laser ablation inductively coupled plasma mass spectrometry (LA-ICP-MS). These high-resolution compositional profiles were combined with a refined ${ }^{230} \mathrm{Th} / \mathrm{U}$-chronology age model constructed from published ${ }^{24}$ and additional new ${ }^{230} \mathrm{Th} / \mathrm{U}$-dates. Based on this improved age model, our new LA-ICP-MS data, and a principal component analysis (PCA), we (i) detect pyroclastic particles incorporated into the stalagmite, (ii) identify and date the ash as $\mathrm{MB}_{2}$ and $\mathrm{MB}_{3}$ tephra of the Mt. Burney eruptions and document further volcanic signals from Mt. Burney and Aguilera. Furthermore, (iii) MA1 recorded the environmental response to changes in the hydrological/pedological regime caused by the eruptions and 
their deposits. In addition, scanning electron microscopy (SEM) and nanoscale secondary ion mass spectrometry (NanoSIMS) of detrital components preserved in selected, distinct lamina were used to support the identification of $\mathrm{MB}_{2}$ and $\mathrm{MB}_{3}$ tephra. Within the context of the new data reported here, previously published stable isotope data $\left(\delta^{18} \mathrm{O}, \delta^{13} \mathrm{C}\right)$ of MA1 ${ }^{24}$ provide additional constraints on shortterm perturbations of the local surface hydrology following both eruptions.

\section{Environmental context and characteristics of the MA1 stalagmite}

The MA1 stalagmite was obtained from the Marcelo Arévalo (MA) cave, situated at $20 \mathrm{~m}$ a.s.1. in the Magellanic moorlands at $52^{\circ} 41.7^{\prime} \mathrm{S} / 73^{\circ} 23.3^{\prime} \mathrm{W}^{24}$ (Fig. 1a). The cave developed in a nearly vertical tectonic fracture zone cross-cutting a plutonic sequence of granitoids, orthogneiss and mafic dykes ${ }^{25}$ (Fig. 1b). The hydrologic system in this fracture zone directly connects the cave with a small catchment $\left(625 \mathrm{~m}^{2}\right)$ at $80 \mathrm{~m}$ a.s.l. that is characterized by acidic, waterlogged peatland soils and surrounding bare rock outcrops ${ }^{25}$ (Fig. 1b). The super-humid climate in this region is controlled by pronounced seasonal variations of the southern westerly wind belt ${ }^{26,27}(\mathrm{SWW})$ and a present annual precipitation of $\sim 3,800 \mathrm{~mm} \mathrm{a}^{-1} 28$ (recorded at the automatic weather station Arévalo, Fig. 1b). Reconstructed annual precipitation during the Late Holocene reached up to $6,500 \mathrm{~mm} \mathrm{a}^{-124}$. Elevated drip rates $(\sim 150-$ $250 \mathrm{~cm}^{3} \mathrm{~d}^{-1}$ ) measured at the MA1 sampling site vary within the seasonal course ${ }^{24}$. An estimated maximum delay of only $4-6$ weeks between major rainfall events and increased drip rates ${ }^{24}$ indicates a relatively high transmissivity of the fractured aquifer system due to a good connectivity of the cave with the local surface hydrology in combination with the extraordinary precipitation. MA1 shows a rather constant mean growth rate of $67 \mu \mathrm{m} \mathrm{a}^{-1}$ (minor variations of $25-100 \mu \mathrm{m} \mathrm{a}^{-1}$ ) and continuous growth over the last $4.5 \mathrm{kyrs} \mathrm{BP}^{24}$.

Fig. 1

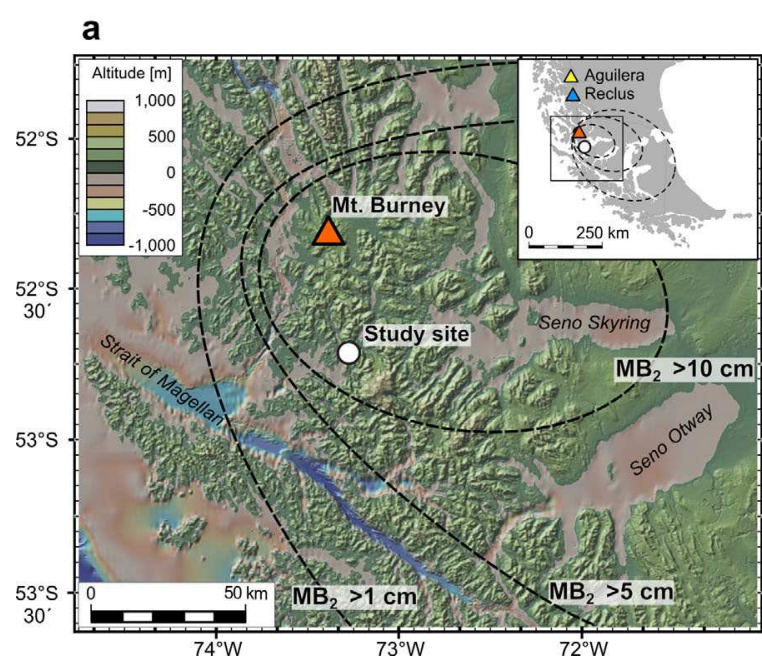

\section{b}

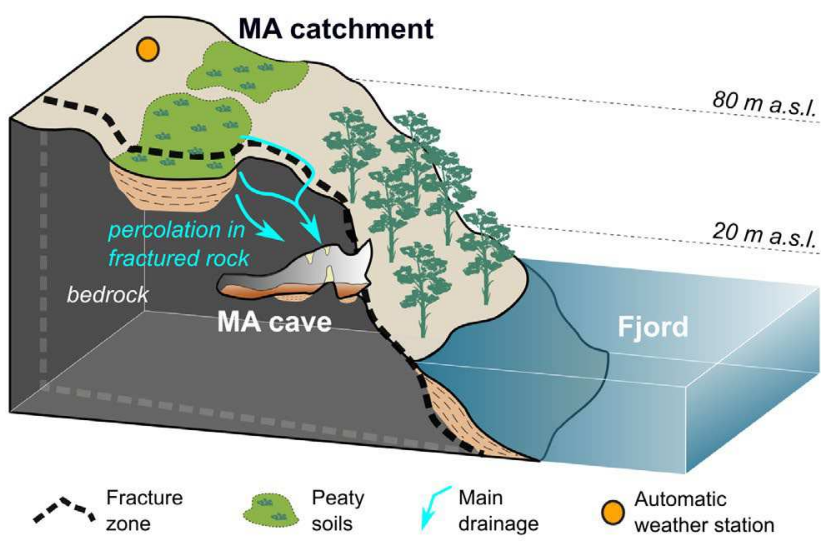


The cave site is located only $40 \mathrm{~km} \mathrm{~S}$ of the Mt. Burney volcano $\left(52^{\circ} 19^{\prime} \mathrm{S} / 73^{\circ} 22^{\prime} \mathrm{W}\right.$, Fig. 1a), the most active volcano of the Austral Volcanic Zone during the Late Quaternary ${ }^{5}$. Originating from this volcano, ten Holocene Plinian eruptions dispersed tephra layers across wide areas of southernmost South America ${ }^{3}$. Particularly after the large-volume $\mathrm{MB}_{2}$ eruption, regional pristine ecosystems suffered a millennium-scale damage caused by a $\mathrm{SO}_{2}$-induced acidification associated with the deposition of $>10 \mathrm{~cm}$ of volcanic ash ${ }^{1,2}$. In contrast, the tephra deposits from the significantly smaller $\mathrm{MB}_{3}$ eruption are only a few millimeters thick ${ }^{12,13}$.

\section{Results}

\section{Chronology}

135 We used StalAge ${ }^{29}$ to construct a new age-depth model for the MA1 speleothem compared to the previous study of Schimpf et al. ${ }^{24}$ (Fig. 2). It is based on $18{ }^{230} \mathrm{Th} / \mathrm{U}$-ages (instead of 16) and a slightly modified correction factor for detrital Th according to Budsky et al. ${ }^{30}$. The results of ${ }^{230} \mathrm{Th} / \mathrm{U}$-dating, including the improved detritus correction, are shown in Table S1. The applied StalAge model for MA1 covers the entire $28 \mathrm{~cm}$ length along the growth axis of the speleothem, representing about 4.8 kyrs. For details of the ${ }^{230} \mathrm{Th} / \mathrm{U}$ age constraints, detritus correction and the construction of the age model, see the

141 "Methods" section.

142 Fig. 2

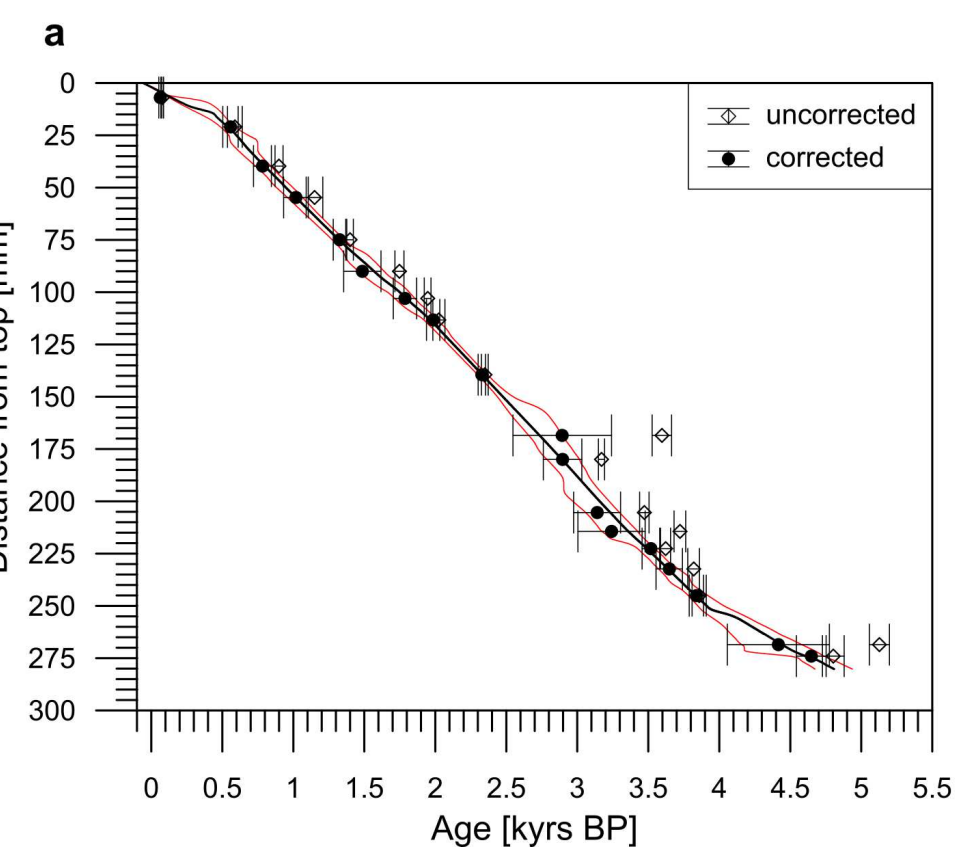

b

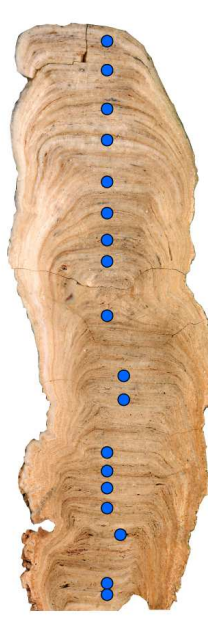


147 Concentrations of $\mathrm{S}, \mathrm{P}, \mathrm{U}, \mathrm{Si}, \mathrm{Sr}$, and $\mathrm{Zr}$ - selected by virtue of the well-known composition of Mt. 148 Burney tephra ${ }^{7,8,31}$ and the environmental impact after the deposition of $\mathrm{MB}_{2}$ ash $^{1}$ - were measured on 149 thin sections prepared along the entire length of MA1 (4.5 to 0.6 kyrs BP) and are presented in Figs. 3-

150 5. Average elemental concentrations were determined from a total 59,200 LA-ICP-MS measurements 151 for S (132 ppm), P (2212 ppm), U (2.4 ppm), Si (1397 ppm), Sr (197 ppm), and Zr (3.2 ppm). Against 152 this background, we observe numerous high amplitude spikes identified as short (few months up to three 153 years) and strong variations in the deposition of these elements. Such peak concentrations reached $154>10 \mathrm{ppm}$ for $\mathrm{U}$ and $\mathrm{Zr},>400 \mathrm{ppm}$ for $\mathrm{Sr},>1,000 \mathrm{ppm}$ for $\mathrm{S}$ and $\mathrm{P}$ and easily exceeded 10,000 ppm in case of Si (Figs. 3-5). These high amplitude spikes are well correlated for S, P, U, Si, Sr, and Zr and appear highly irregular with respect to frequency and intensity along the profiles. Particular conspicuous spikes of S, P, U, Sr, and partly Zr, occur at 0.853, 2.291, 2.978 and 4.216 kyrs BP (Fig. 3). At 4.216 and 2.291 kyrs BP (highlighted by orange bars; Fig. 4), both peaks are followed by (i) a series of smaller, but equally discrete, short-term spikes for the same elements decreasing in height or by (ii) more extended periods characterized by consistently elevated concentrations from $\sim 4.20$ to $4.15 \mathrm{kyrs}$ BP, respectively (gray bars; Fig. 4). As would be expected for elements that are contributed from detrital silicate, Si should be closely related with Zr. Indeed, Fig. 5 shows that a large number of LA-ICP-MS measurements fall on a tight correlation trend that projects from the origin with a $\mathrm{Si} / \mathrm{Zr}$ ratio of 3300 towards the composition of $\mathrm{MB}_{2}$ glass with average values of $77 \mathrm{wt} . \% \mathrm{SiO}_{2}$ and $110 \mathrm{ppm} \mathrm{Zr}^{7,8}$. This trend with this $\mathrm{Si} / \mathrm{Zr}$ ratio therefore represents a mixing line between two endmembers: the $\mathrm{Si}$ - and $\mathrm{Zr}$ - rich $\mathrm{MB}_{2}$ glass and the $\mathrm{Si}$ - and $\mathrm{Zr}$-free, $\mathrm{CaCO}_{3}$ rich matrix of the speleothem. More elevated concentrations of $\mathrm{Zr}$ and Si (Fig. 5a) are an artifact from the normalization to Ca in LA-ICP-MS measurements that include significant but unknown amounts of a non-carbonate component (i.e. tephra, which is lower in Ca compared to the carbonate). This artifact in the concentration data is (i) not avoidable and (ii) does not affect the characteristic $\mathrm{Si} / \mathrm{Zr}$ ratio of the ash component. However, a large number of analyses fall off this correlation trend (Fig. 5) and can be attributed to silicate minerals derived from basement rocks. One additional component is thus identified as particular rich in $\mathrm{Si}$ (and low in $\mathrm{Zr}$ ) and probably represents quartz, whereas a few data points tend towards high $\mathrm{Zr}$ and may be caused by traces of detrital zircon. 
Fig. 3

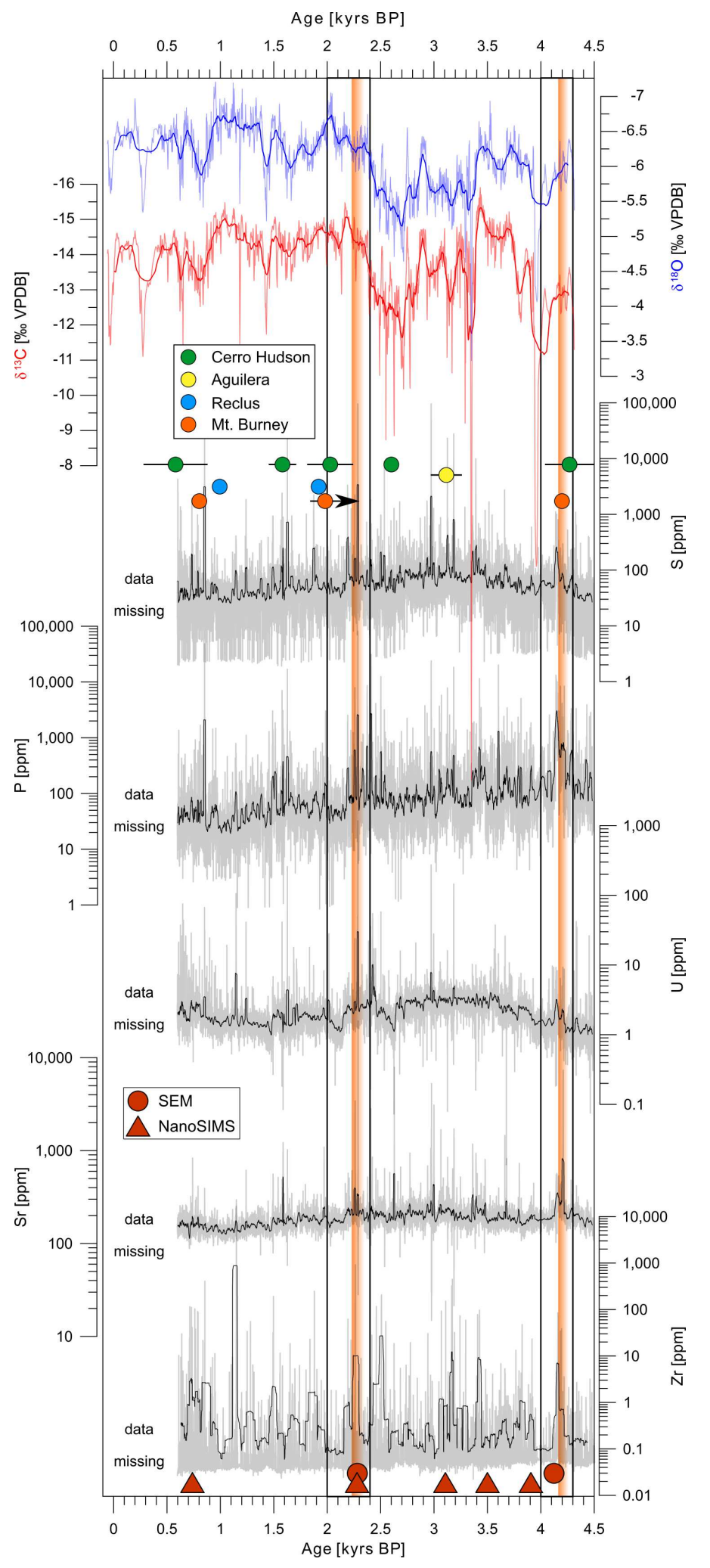




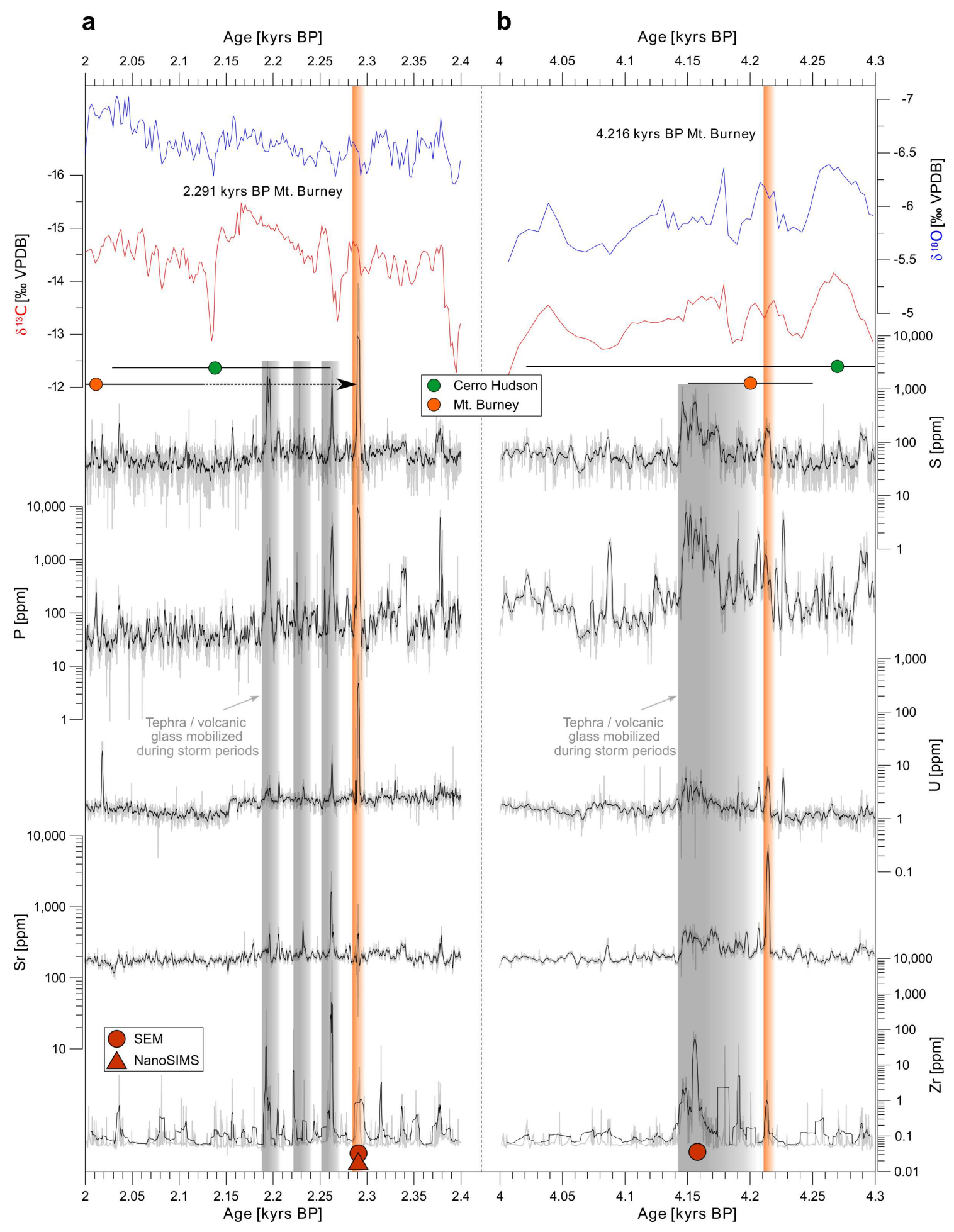


Fig. 5
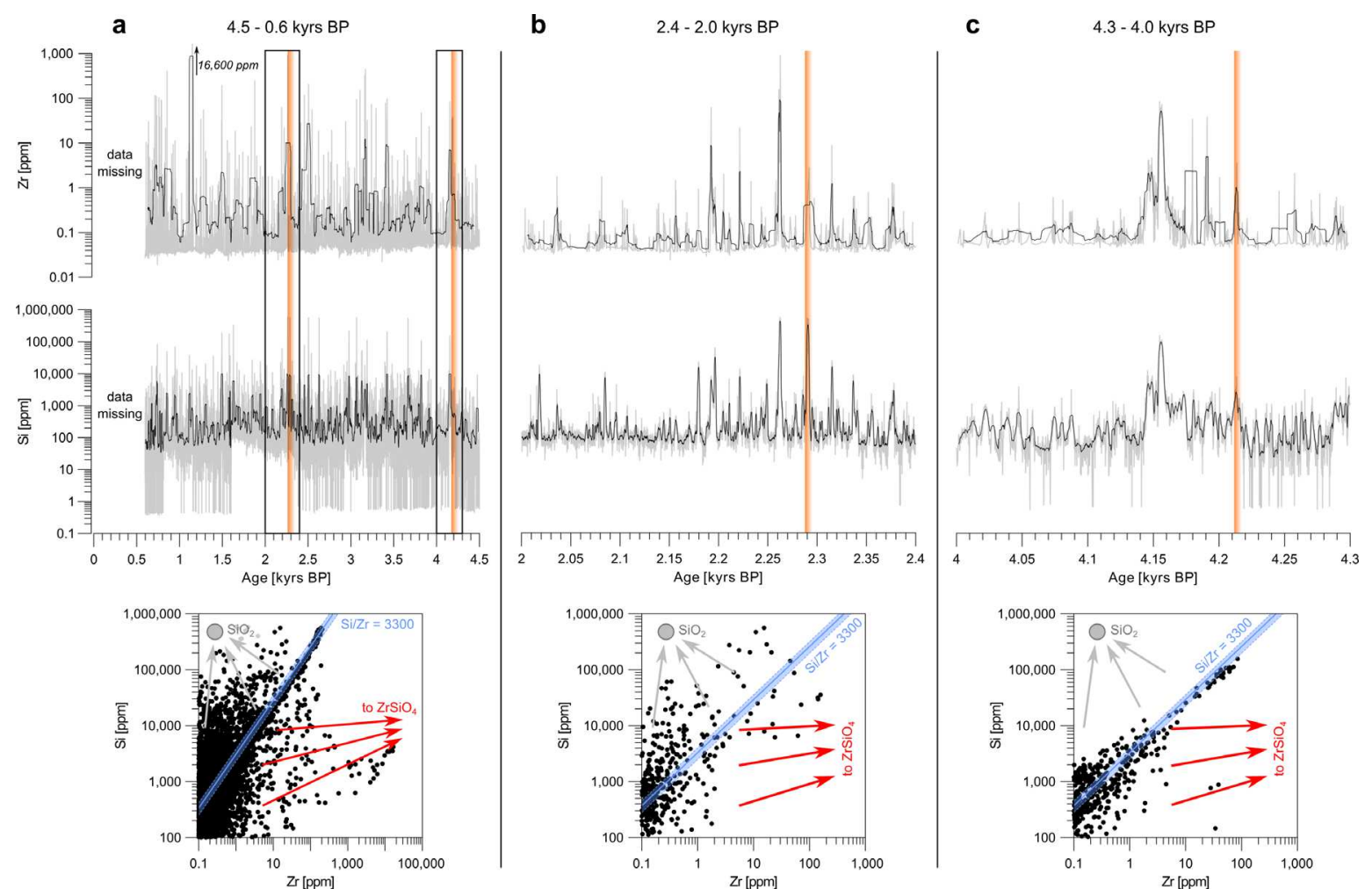

In order to further characterize elemental peaks of $\mathrm{Si}, \mathrm{Zr}, \mathrm{S}$ and other elements in the speleothem record and to provide for tests that these may represent volcanic signals, we analyzed the data set using a $\mathrm{PCA}^{22,32}$. The first three principal components (PC) explained $80.7 \%$ of the variability within the entire data set (Figs. 6 and S1, and Table S2). High scores for PC-1 (44.4\%), PC-2 (19.4\%) and PC-3 (16.9\%) reflected the correlated trace element peaks as discussed above and displayed in Figs. 3-5. PC-1 had high loadings of S, P, U and Si, whereas PC-2 loadings mirrored mainly Si and Sr. Zr was dominantly loaded on PC-3. High PC scores, particularly of PC-1, suggest distinct depositional events at 0.853 , 4.15 kyrs BP and synchronous spikes from 2.27 to 2.17 kyrs BP. 
Fig. 6
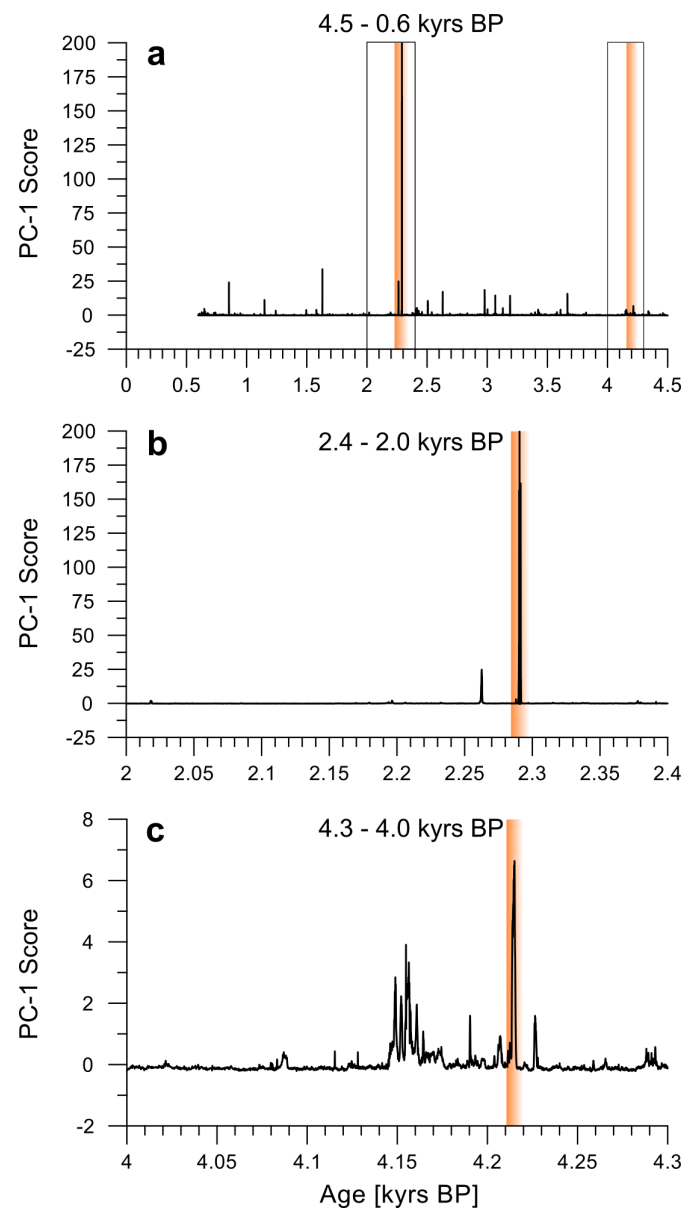

197 Images obtained from SEM of detrital siliciclastic components in laminae at 4.15 and 2.20 kyrs BP

198 where PC scores and concentrations of Si and Zr are high are shown in Figs. 7a-c. Some layers were 199 found to be particularly rich in fragments of pyroclastic material (Fig. S3), comprised of either vesicular 200 glass shards (Fig. 7a; 2.20 kyrs BP) or phenocrysts glazed with a thin coating of volcanic glass (Figs. $2017 \mathrm{~b}-\mathrm{c} ; 4.15 \mathrm{kyrs}$ BP). These images document the perfect preservation of micro-tephra that were included 202 during the growth of the speleothem. 

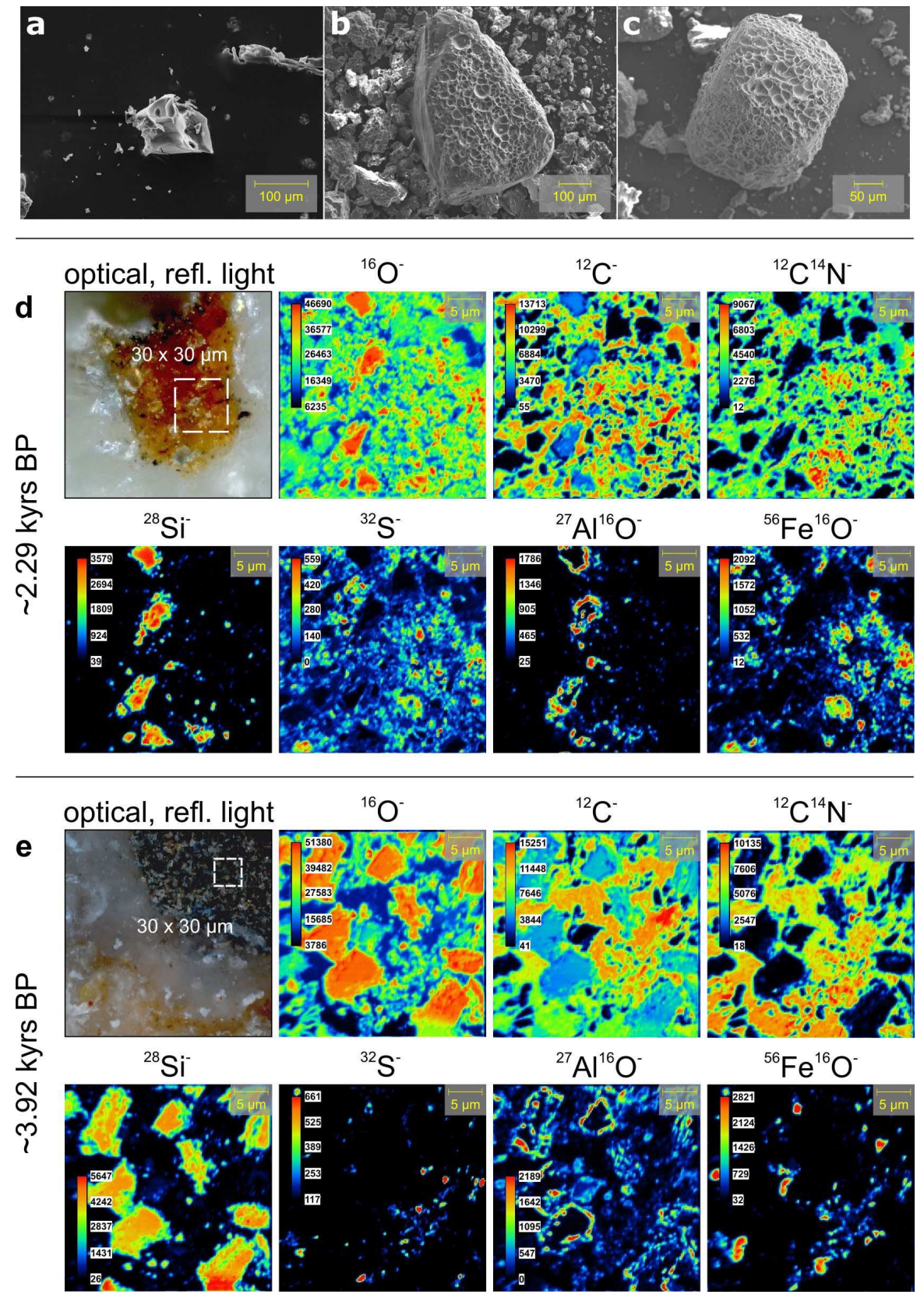

206 Detritus-rich inclusions were further analyzed in-situ by NanoSIMS (Figs. 7d-e and S2). The $30 \times 30 \mu \mathrm{m}$ 207 measurement spots focused on non-carbonate materials accumulated in lamina sections at $\sim 3.92$ and

$208 \sim 2.29 \mathrm{kyrs}$ BP. Elevated ${ }^{28} \mathrm{Si}^{-}$and ${ }^{16} \mathrm{O}^{-}$secondary ion counts indicate an enrichment of irregularly shaped, 209 in part porous siliciclastic particles of 5 to $15 \mu \mathrm{m}$ size which are framed by thin rims that are high in $210{ }^{27} \mathrm{Al}^{16} \mathrm{O}^{-}$counts (Figs. 7d-e and S2a). ${ }^{12} \mathrm{C}^{-}$and ${ }^{12} \mathrm{C}^{14} \mathrm{~N}^{-}$demonstrate that these micron scale particles are 211 embedded in a matrix of $\mathrm{OM}$ with dispersed $\mathrm{Fe}$ and $\mathrm{Al}$ as indicated by spots of ${ }^{56} \mathrm{Fe}^{16} \mathrm{O}^{-}$and ${ }^{27} \mathrm{Al}^{16} \mathrm{O}^{-}$.

212 NanoSIMS measurements on inclusions at $\sim 3.50$ and $\sim 3.11$ kyrs BP did not detect intact siliciclastic 213 particles (Figs. S2b-c). Spots with higher ${ }^{28} \mathrm{Si}^{-},{ }^{27} \mathrm{Al}^{16} \mathrm{O}^{-}$, and ${ }^{56} \mathrm{Fe}^{16} \mathrm{O}^{-}$counts appear as fine flaky 214 structures. These structures occur scattered throughout the observed areas and correlate with high ${ }^{12} \mathrm{C}^{-}$, 
${ }^{12} \mathrm{C}^{14} \mathrm{~N}^{-}$, and ${ }^{32} \mathrm{~S}^{-}$signals from OM. Grains of bedrock-derived mineral detritus, such as quartz, were identified at $\sim 0.73 \mathrm{kyrs}$ BP by strong localized signals of ${ }^{28} \mathrm{Si}^{-}$and absence of any other elements (Fig. $\mathrm{S} 2 \mathrm{~d})$. However, in this case, thin ${ }^{27} \mathrm{Al}^{16} \mathrm{O}^{-}$-rims have not been observed.

\section{Discussion}

Identifying volcanic input by compositional spikes of characteristic elements in the MA1 record provides means for precise dating and the correlation of volcanic ash inputs into Patagonian soils and environmental archives 9 . In order to identify such volcanic signals, we need to consider the direct primary elemental deposition from tephra, volcanic volatiles and leached components. In addition, there may be a secondary response to tephra deposition on peatland soils that potentially affects nutrient cycling $^{33}$, chemical leaching ${ }^{15,16}$, and soil $\mathrm{C}$ stocks ${ }^{34,35}$. Pristine peatland ecosystems such as those of southern Patagonia may be particularly sensitive to such volcanic impacts with high tephra-loading and variable climate conditions ${ }^{\mathbf{1}, 36}$. Finally, we will address the implications and improved age constraints of tephra signals that we detected in the MA1 speleothem.

The primary elemental deposition and leaching from tephra comes from a contribution of fine-grained glassy tephra particles and is identified by synchronous and sharp peaks of $\mathrm{Zr}$ and Si. These peaks indicate the accumulation of volcanic glass at and after 4.216 and 2.291 kyrs BP (Fig. 5) and identifies the ash component by its $\mathrm{Si} / \mathrm{Zr}$ ratio of about 3300 which is similar to $\mathrm{MB}_{2}$ glass (Fig. 5). These primary tephra signals also determine the high amplitude spikes of PCs $1-3$ (Figs. 6 and S1). The presence of tephra fragments in the stalagmite is verified by SEM imaging in Figs. 7a-c. The structure of observed shards and vesicle-rich glass coatings on phenocrysts resemble characteristics of the well-documented Mt. Burney tephra ${ }^{1,7,8,13,31}$. Indications of recurring tephra input over time spans of $60 \mathrm{yrs}$ are found also directly after the 4.216 and 2.291 kyrs BP ashfall events by continued elevated $\mathrm{Zr}$ and Si contents at $4.20,4.18,4.14$ and 2.26, 2.20, 2.19 kyrs BP (Fig. 5). This additional siliciclastic input is most likely caused by repeated periods of tephra reworking and deposition caused by distinct storm events $\mathbf{s}^{\mathbf{9} 26}$. Owing to differences in rainfall ${ }^{24}$ shown by variable $\delta^{18} \mathrm{O}$ and $\delta^{13} \mathrm{C}$ levels in (Figs. 3-4), a climateinduced influence on the hydrological soil-to-stalagmite transport is suggested, explaining a slightly dissimilar response to tephra fallout recorded by the MA1 stalagmite during 4.5-4.0 kyrs BP compared to $2.5-2.0$ kyrs BP.

Micron-sized volcanic glass fragments with superficial alteration rims were observed by NanoSIMS analyses (Figs. 7d-e and S2a). Their texture differs significantly from bedrock-derived silicates (Fig. S2d). These images identify rims rich in ${ }^{27} \mathrm{Al}^{16} \mathrm{O}^{-}$around the glass particles indicating the formation of secondary alumino-silicates ${ }^{37}$. This is consistent with recent studies that documented pronounced glass leaching and deposition of Al-(hydr)oxides related to tephra weathering in other humid acidic environments ${ }^{16,38,39}$. The close textural relation between ${ }^{27} \mathrm{Al}^{16} \mathrm{O}^{-}$-enrichments and $\mathrm{OM}\left({ }^{12} \mathrm{C}^{14} \mathrm{~N}^{-}\right)$ 
surrounding the observed particles (Figs. 7d-e and S2a) suggests that the leaching processes likely occurred in-situ in the micro-chemical environment at the stalagmite surface and during the deposition of the tephra particles.

Apart from this in-situ alteration of glass shards and their incorporation into the growing stalagmite, there will also be secondary effects in soils as a response to volcanic fallout. Various volcanogenic chemical compounds dissolve rapidly in surface environments after the direct wet deposition of acid rain from the eruption plume and/or after leaching by water from freshly deposited tephra ${ }^{15,33}$. Typical chemical compounds leached from pristine tephra are sulfates and a range of soluble salts containing other mobile and volatile metals ${ }^{33}$. Here, we focus on $\mathrm{S}, \mathrm{P}, \mathrm{Sr}$ and $\mathrm{U}$ to trace solutes potentially derived from Mt. Burney tephra that has been identified here and for which the composition is well $\mathrm{known}^{\mathbf{7 , 8 , 3 1}}$. While chemical signals indicate the prolonged chemical effect of tephra deposition (i.e. elevated $\mathrm{Si}, \mathrm{Sr}$ and $\mathrm{Zr}$ in Figs. 3 and 5), pristine tephra particles are absent in speleothem lamina at $\sim 3.50$ and $\sim 3.11$ kyrs BP (Figs. S2b-c). During this time, Kilian et al. ${ }^{1}$ documented a millennium-scale acidification phase in regional soils following the Plinian $\mathrm{MB}_{2}$ eruption. This may have caused efficient chemical alteration of tephra and transport of leached elements from the catchment to the speleothem. Accordingly, we observe correlated patterns of ${ }^{12} \mathrm{C}^{14} \mathrm{~N}^{-},{ }^{28} \mathrm{Si}^{-},{ }^{27} \mathrm{Al}^{16} \mathrm{O}^{-}$, and ${ }^{56} \mathrm{Fe}^{16} \mathrm{O}^{-}$counts in NanoSIMS images of the speleothem during this period (Figs. S2b-c), which indicate the accumulation of silicate weathering products together with $\mathrm{OM}^{37,40}$. These residues are typical for the decomposition of glassy tephra in acidic soils and are likely comprised of organo-mineral complexes enriched in Al-/Fe-(hydroxides) and silica gels ${ }^{16,38,39}$. The low $\mathrm{pH}$ of $3.9-5.4$ in soils of the MA catchment ${ }^{25}$ may also promote mobilization of water-soluble $\mathrm{Sr}$ and $\mathrm{U}$ from fresh volcanic glass ${ }^{17,33}$. We therefore interpret the short-term release of $\mathrm{Sr}$ and $\mathrm{U}$ as a signal of tephra leaching in acidic waterlogged peat soils ${ }^{\mathbf{1 1 4}}$ at 4.216 and $2.291 \mathrm{kyrs} \mathrm{BP}$ (Figs. 3-4). We associate the periodically increasing Sr and U concentrations in time periods following the eruptions with the storm phase-induced incorporation of leached elements from tephra in the catchment. The high peaks of $\mathrm{Sr}$ could additionally be explained by a contribution from plagioclase phenocrysts ${ }^{21,22}$ embedded in MA1 (e.g., mineral components in Figs. 7b-c), which are - next to volcanic glass - a dominant component of tephra from Mt. Burney ${ }^{7,31}$.

PCA results (Figs. 6 and S1, Table S2) discriminate two different domains covered by element concentrations in MA1. PC-1 mainly reflects high concentrations of presumably volcanogenic $\mathrm{SO}_{4}{ }^{2-}$ and $\mathrm{PO}_{4}{ }^{3-15,18,22}$. Second, we expect a simultaneous mobilization of S- and P-bearing species adsorbed to pedogenic $\mathrm{OM}^{41,42}$ due to the sudden perturbation of peat soil hydro-chemistry after ashfall ${ }^{1,2,36}$. Accordingly, high amounts of detected ${ }^{32} \mathrm{~S}^{-},{ }^{12} \mathrm{C}^{-}$and ${ }^{12} \mathrm{C}^{14} \mathrm{~N}^{-}$secondary ions counts (Figs. 7 and S2) imply a direct linkage between soil $\mathrm{OM}$ and $\mathrm{S}$ in the stalagmite ${ }^{43,44,45}$, as $\mathrm{OM}$ is obviously not associated with the composition of fresh tephra ${ }^{33}$. In addition, PC-1 implies a contribution of siliciclastic components in the form of fine-grained detrital materials in combination with intense leaching processes with mobilization, transport and deposition of mobile lithophile elements from rock substrate or tephra 
in soils. PC-2 and PC-3 primarily mirror siliciclastic components without a concurrent deposition of volcanogenic $\mathrm{SO}_{4}{ }^{2-}$ and $\mathrm{PO}_{4}{ }^{3-}$. According to Jamieson et al. ${ }^{22}$, volcanic signals in a speleothem do not automatically produce a clear corresponding chemical excursion in the stalagmite stratigraphy. However, in our particular case, all three PCs are indicative of volcanic impacts on the soil-to-stalagmite transfer and deposition system. During the observed periods, PC-1 main spikes (Fig. 6) coincide well with peaks of the lithophile elements ( $\mathrm{Si}, \mathrm{Sr}, \mathrm{Zr}$ and $\mathrm{U}$ ) as well as $\mathrm{S}$ and $\mathrm{P}$ concentrations (Figs. 3-5). Such high amplitude compositional spikes, significantly exceeding average concentrations, are comparable to characteristic volcanic signals observed in other speleothems ${ }^{18,20,21,22,23}$. According to our reasoning above, these distinct compositional peaks suggest volcanic events at 4.216 and $2.291 \mathrm{kyrs}$ BP (Figs. 3-6 and S1).

We also observe variations of $\delta^{18} \mathrm{O}$ and $\delta^{13} \mathrm{C}$ signatures ${ }^{24}$ by 1 to $1.5 \%$ in the record following these 4.216 and $2.291 \mathrm{kyrs} \mathrm{BP}$ events. $\delta^{18} \mathrm{O}$ and $\delta^{13} \mathrm{C}$ first decrease for ca. 10 years followed by higher values lasting for $\sim 20$ yrs (Fig. 4). We interpret these isotopic changes as a combined effect of varying rainfall intensity and short-term perturbations of the hydro-chemical soil system within the catchment subsequent to tephra deposition ${ }^{21}$. Environmental changes such as variations in redox-pH conditions, water table fluctuations and plant decomposition may strongly affect the release of dissolved organic matter (DOM) from peat soils ${ }^{46,47}$. DOM can percolate into cave drip waters and be recorded in $\delta^{13} \mathrm{C}$ signatures of speleothems $\mathbf{2 0}^{\mathbf{2 0 , 4 3 , 4 4 , 4 5}}$. The close relationship between the abundance of OM that derives from drip water DOM and ${ }^{12} \mathrm{C}^{-}$and ${ }^{12} \mathrm{C}^{14} \mathrm{~N}^{-}$signals in detritus-rich laminae of MA1 is shown by the NanoSIMS measurements ${ }^{40}$ (Figs. 7d-e and S2). Therefore, the link between detrital and volcanic input in MA1 and the fundamental changes in soil chemistry and hydrology in the catchment is clearly documented.

Finally, an import of elements such as S and $\mathrm{Sr}$ in the MA catchment area can also occur by sea salt aerosols $\mathbf{2 4 , 4 8 , 4 9}$. However, sea salt contribution from the nearby Pacific Ocean through surface deposition and transfer to cave drip waters is responsible for overall elevated concentrations compared to more “continental” speleothems ${ }^{21,22,23,50}$. Such speleothems contain concentrations of, i.e., Sr ranging between 10 and $20 \mathrm{ppm}^{22,50}$. Consistent and strong SWW-induced wind velocities and frequent storm events in the region,26 cause a constant deposition of sea spray-derived elements. These elements are characterized by short residence times in waterlogged peatland soils ${ }^{14}$ and therefore we argue that the high annual precipitation 9,28 leads to a persistent input and "excess" sea salt $\mathrm{S}$ and $\mathrm{Sr}$ signatures in the speleothem. Thus, sea salt-derived S and Sr must be of secondary importance for the distinct high amplitude spikes of these elements, because their deposition would not result in the documented compositional spikes and a close correlation that we observed with other mobile and immobile lithophile trace elements (e.g., Si and Zr, Figs. 3-5) would not be expected. stalagmite recorded distinct volcanic events for which we can determine precise ages from the refined 
age-depth model using the StalAge algorithm ${ }^{29}$ with errors represented by $95 \%$ confidence limits (Fig. 2a).

Based on ${ }^{230} \mathrm{Th} / \mathrm{U}$-ages, these eruptions can now be dated more precisely to $4216^{+93} /-193$ yrs BP $\left(\mathrm{MB}_{2}\right)$ and $2291 \pm 33 \mathrm{yrs} \mathrm{BP}\left(\mathrm{MB}_{3}\right)$. The ${ }^{230} \mathrm{Th} / \mathrm{U}$-age for the $\mathrm{MB}_{2}$ eruption is in good agreement with the ${ }^{14} \mathrm{C}$ age of $4200 \pm 50 \mathrm{cal}$ yrs BP published by Breuer et al. ${ }^{51}$, which is based on macro-plant remains included in the $>10 \mathrm{~cm}$ thick $\mathrm{MB}_{2}$ ash deposit. Our new $\mathrm{MB}_{3}$ age falls into the lowermost range of bracketing ${ }^{14} \mathrm{C}$-ages presented by Biester et al. ${ }^{12}$ and Kilian et al. ${ }^{13}$. At that time, the $\mathrm{MB}_{3}$ eruption was only roughly dated to $\sim 2020 \pm 90$ cal $\mathrm{yrs} \mathrm{BP}^{12,13}\left(>1830 \pm 40\right.$ and $<2210 \pm 90 \mathrm{cal} \mathrm{yrs} \mathrm{BP}^{12},>1980 \pm 40$ and $<2060 \pm 90$ cal yrs $\left.\mathrm{BP}^{13}\right)$. This new age is therefore more precise than previous datings.

Following our arguments developed above, our trace element profiling and PCA analysis (Figs. 3, 5, 6 and S1), an additional volcanic event at $853^{+41} /-60$ yrs BP is clearly indicated by the data of this study. This eruption can be correlated to the $\mathrm{MB}_{4}$ tephra deposit from Mt. Burney, which was only poorly dated by stratigraphic correlation $\left(\sim 800 \mathrm{yrs} \mathrm{BP}^{3}\right)$. With a reported ${ }^{14} \mathrm{C}$-age between $\sim 3067$ and 3339 cal yrs $\mathrm{BP}^{7}$, the $\mathrm{A}_{1}$ eruption from the remote Aguilera stratovolcano is one further potential candidate for a more precise dating. We found a matching volcanic signal in MA1 with a ${ }^{230} \mathrm{Th} / \mathrm{U}$-age of $2978^{+91} /-104$ yrs BP. This is in accordance with the regional distribution of $\mathrm{A}_{1}$ tephra ${ }^{7}$, which has also been discovered in lake sediments nearby the MA cave site $^{13}$.

With this successful identification of volcanic eruptions, we propose that our high-resolution speleothem archive has probably documented the impact of further ashfall events from other, more distal volcanic centers of the Southern and Austral Volcanic Zones. In contrast to typical geochemical fingerprinting, trace element variations in MA1 enable precise age constraints for a refinement of existing tephrochronologies. For example, the peaks of S concentrations in MA1 (Figs. 3-4) likely recorded atmospheric signals of further volcanoes, such as Reclus and Cerro Hudson, and other high-magnitude volcanic events in the southern hemisphere off South America. This opens the possibility of correlation with Antarctic ice cores $^{52}$ to evaluate large-scale southern hemispheric patterns of Late Holocene volcanism.

We conclude that the unique, sub-annually resolved speleothem LA-ICP-MS data presented here might constitute an important contribution to the Late Holocene tephrochronology of southernmost South America. This will allow a better understanding of the volcanic history in the region, and an improvement for the reconstruction of paleoclimate and paleoenvironmental conditions from regional geological archives. Besides well-preserved tephra layers, MA1 provides multiple climatically and environmentally important information due to its unique nature as a non-karst stalagmite with enclosed manifold detrital components. This information includes potential feedback signals to SWW dynamics and environmental impacts of regional volcanism back to $\sim 4.8$ kyrs BP, which document the evolution of one of the most remote and pristine ecosystems worldwide ${ }^{9,26}$. 


\section{Methods}

\section{Chronology}

Stalagmite MA1 was dated at the Heidelberg Academy of Sciences. Sample preparation and analytical methods were described in detail by Schimpf et al. ${ }^{24}$. We included two additional samples (Lab. No. 3672 and 3436, Table S1) that were not considered in Schimpf et al. ${ }^{24}$ due to their large content of detrital ${ }^{232} \mathrm{Th}$. Stalagmite MA1 generally contains high amounts of detrital Th. This is obvious from the ${ }^{230} \mathrm{Th} /{ }^{232} \mathrm{Th}$ activity ratios that range from 4.257 to 93.70 (Lab. No. 3672 and 3653, Table S1). However, these values are well below the limit of $>200$ suggesting insignificant detrital contamination ${ }^{53}$. Detrital contamination of MA1 also results in age inversions (i.e., uncorrected ages that are not in stratigraphic order). For instance, the sample with Lab. No. 3435 at $268.5 \mathrm{~mm}$ distance from top is significantly older (5.128 kyrs BP) than the sample below at $274 \mathrm{~mm}$ distance from top (4.803 kyrs BP).

Schimpf et al. ${ }^{24}$ assumed a ${ }^{232} \mathrm{Th} /{ }^{238} \mathrm{U}$ weight ratio of $4.8 \pm 50 \%$ for the detritus, which resulted in a smooth age-depth relationship. This value agrees with the conventionally used value for the upper continental crust $\left(3.8 \pm 1.9^{54}\right)$. Here we used a different approach to account for detrital contamination, based on an algorithm recently published by Budsky et al. ${ }^{30}$. This algorithm calculates corrected ages assuming a specific ${ }^{232} \mathrm{Th} /{ }^{238} \mathrm{U}$ weight ratio of the detritus and ${ }^{230} \mathrm{Th},{ }^{234} \mathrm{U}$ and ${ }^{238} \mathrm{U}$ in secular equilibrium, and then determines the ${ }^{232} \mathrm{Th} /{ }^{238} \mathrm{U}$ weight ratio of the detritus, which results in a minimum sum of age inversions (in years). For stalagmite MA1, this approach results in a ${ }^{232} \mathrm{Th} /{ }^{238} \mathrm{U}$ weight ratio of the detritus of 3.69, which is close to the mean value of the upper continental crust ${ }^{54}$ and in agreement within error with the value used by Schimpf et al. ${ }^{24}$. As suggested by Budsky et al. ${ }^{30}$, we assumed a conservative uncertainty of $\pm 50 \%$ for the determined ${ }^{232} \mathrm{Th} /{ }^{238} \mathrm{U}$ ratio of the detritus. Fig. 2a shows a comparison of the uncorrected and the corrected ages.

The final age-depth model for MA1 (Fig. 2a) was calculated in $R^{55}$ using the Monte-Carlo-based StalAge algorithm ${ }^{29}$, which has been specifically designed for speleothems. In contrast to the previously used Akima interpolation, StalAge provides $95 \%$ confidence limits, which allows to assess the uncertainty of the age model.

\section{LA-ICP-MS data}

The MA1 stalagmite was analyzed with laser ablation inductively coupled plasma mass spectrometry (LA-ICP-MS) at GZG, University of Göttingen. LA-ICP-MS elemental analyses were performed as ablation tracks on 14 overlapping, $30 \mu \mathrm{m}$ thick and $40-50 \mathrm{~mm}$ long polished thin sections covering the growth axis of the stalagmite from 24 to $280 \mathrm{~mm}$ (distance from top, Fig. S3). The thin sections were the same as for electron microprobe analyses presented in Schimpf et al. ${ }^{24}$. The ICP-MS used was a Perkin Elmer ELAN DRC II Q-ICP-MS coupled to a Lambda Physik COMPex 110 Argon Fluoride laser $(193 \mathrm{~nm})$ with a GeoLas optical bench by MikroLas and a small volume sample chamber. The 
ablation setup was operating with a beam width of $120 \mu \mathrm{m}$, a repetition rate of $10 \mathrm{~Hz}$ for the laser pulses

392 (dwell time $40 \mathrm{~ms}$ per isotope, $1.078 \mathrm{~s}$ per sweep) and a scan speed of $20 \mu \mathrm{m} \mathrm{s}^{-1}$. Background data were

393 taken before and after the measurements for $2-3$ minutes. The measurements were calibrated to the

394 standards NIST610 and NIST612 by bracketing analyses and the internal standard ${ }^{43} \mathrm{Ca}$ was used to

395 convert the measurements into absolute concentrations. Matrix effects between NIST610/NIST612 and

$396 \mathrm{CaCO}_{3}$ were considered to contribute less than $10 \%$ error. Measured isotopes were ${ }^{27} \mathrm{Al},{ }^{29} \mathrm{Si},{ }^{31} \mathrm{P},{ }^{34} \mathrm{~S}$,

$397{ }^{43} \mathrm{Ca},{ }^{88} \mathrm{Sr},{ }^{90} \mathrm{Zr}$ and ${ }^{238} \mathrm{U}$. Element concentrations have been stoichiometrically normalized to

$398400,000 \mathrm{ppm}{ }^{43} \mathrm{Ca}$, assuming that the stalagmite is composed of $100 \% \mathrm{CaCO}_{3}$. Background was

399 subtracted and baseline drift corrected. For ablation spots on lamina with more than $10 \%$ detrital

400 siliciclastic material (minerals/volcanic glass containing significantly lower Ca compared to speleothem

$401 \mathrm{CaCO}_{3}$ ), the internal normalization to ${ }^{43} \mathrm{Ca}$ will result in systematically higher values for lithophile

402 elements. However, their elemental ratios (e.g., $\mathrm{Si} / \mathrm{Zr}$ ) will be unaffected.

403 The final LA-ICP-MS record was compiled by aligning the overlapping ablation tracks using a "wiggle-

404 matching" technique based on Al concentrations measured - taking small-scale variations of lamina

405 thickness into account. It is characterized by sub-annual resolution of in total 59,200 LA-ICP-MS

406 measurements covering a time span of 4212 years $(4.809-0.597 \mathrm{kyrs}$ BP). Finally, the consistency of

407 the LA-ICP-MS data set with already published ICP-MS drill core data ${ }^{24}$ was ensured by matching

408 averaged concentrations of the LA-ICP-MS measurements with the contents previously determined by

409 ICP-MS. For this purpose we chose $\mathrm{U}$ as soluble, calcite-compatible element ${ }^{24}$ and used the original

410 drilling diameter of $1.5 \mathrm{~mm}$ in accordance with the exact distance from top for every single coring point

411 to calculate the average of the LA-ICP-MS concentrations for comparison ( 290 LA-ICP-MS

412 measurements per drill core). LA-ICP-MS and ICP-MS U concentrations are in good agreement and

413 correlate with $r=0.68$ (Fig. S4).

414 The principal component analyses (PCA) for the assessment of speleothem high-resolution LA-ICP-MS

415 data was done according to Orland et al. ${ }^{32}$ and Jamieson et al. ${ }^{22}$. The PCA was performed with Origin

416 (version Pro 2019b) to further constrain the occurrence of signals derived from volcanic activity in MA1

417 and was calculated for the trace elements $\mathrm{P}, \mathrm{S}, \mathrm{Sr}, \mathrm{Si}, \mathrm{Zr}$ and $\mathrm{U}$ after Z-score normalization.

419 Stalagmite sections formed during and after the two Plinian eruption periods of the Mt. Burney volcano 420 at $2.0-2.3 \mathrm{kyrs} \mathrm{BP}$ and $3.8-4.2 \mathrm{kyrs} \mathrm{BP}$, and during the millennium-scale acidification phase $(\sim 3.50$ 421 and $\sim 3.11$ kyrs BP) after the $\mathrm{MB}_{2}$ eruption ${ }^{1}$ include laminae rich in detrital components. Representative 422 samples of these sections were taken from the identical blocks the thin sections were prepared of 423 (examples in Fig. S3) and have been investigated with SEM and NanoSIMS. The samples contain the 424 same detritus-rich laminae as analyzed by LA-ICP-MS. We chose NanoSIMS because this technique 
allows to differentiate embedded inorganic (e.g., ${ }^{28} \mathrm{Si}^{-}$) and particularly organic (e.g., $\left.{ }^{12} \mathrm{C}^{14} \mathrm{~N}^{-}\right)$ components from ubiquitous, very low electrically conductive $\mathrm{CaCO}_{3}{ }^{56,57}$.

427 SEM imaging was conducted with a LEO 435VP and a JEOL JXA-89000 RL at the Geology Department of Trier University and the GZG, University of Göttingen. Replicate samples were analyzed after dissolution in $5 \mathrm{M}$ ultra-pure $\mathrm{HCl}$ and an acidic acetate buffer solution ${ }^{58}$ to extract incorporated detritus. An acceleration voltage of $15 \mathrm{kV}$ was applied to produce high-resolution images in secondary electron and back-scattered electron mode.

Prior to NanoSIMS measurements, samples were documented by optical microscopy. NanoSIMS analyses were carried out at the Chair of Soil Science of the Technical University of Munich with a Cameca NanoSIMS 50L using a $\mathrm{Cs}^{+}$primary ion beam with an impact energy of $16 \mathrm{keV}$. The selected stalagmite samples were polished and coated with a conductive Au/Pd layer (ca. $30 \mathrm{~nm}$, Polaron Emitech SC7640 sputter coater) to account for charging during the measurements. Charging was additionally compensated using the electron flood gun of the NanoSIMS. Contaminants and the $\mathrm{Au} / \mathrm{Pd}$ coating layer were locally sputtered away using a high primary beam current (pre-sputtering/implantation), while the reactive $\mathrm{Cs}^{+}$ions were implanted into the sample. The secondary ion yields were enhanced until reaching a steady state. The primary beam (ca. $2 \mathrm{pA}$ ) was focused at a lateral resolution of ca. $120 \mathrm{~nm}$ and was scanned over the sample, with ${ }^{12} \mathrm{C}^{-},{ }^{16} \mathrm{O}^{-},{ }^{12} \mathrm{C}^{14} \mathrm{~N}^{-},{ }^{28} \mathrm{Si}^{-},{ }^{32} \mathrm{~S}^{-},{ }^{27} \mathrm{Al}^{16} \mathrm{O}^{-}$, and ${ }^{56} \mathrm{Fe}^{16} \mathrm{O}^{-}$secondary ions collected on electron multipliers with an electronic dead time fixed at $44 \mathrm{~ns}$. To accurately separate mass isobars, a suitable mass resolution was achieved with appropriate slits and apertures (D1_3, ES_3, AS_2). The secondary ions were recorded using a dwell time of $1 \mathrm{~ms} \mathrm{pixel}^{-1}$, with $256 \times 256$ pixels for a $30 \times 30 \mu \mathrm{m}$ field of view with 30 planes per scan. Single planes were corrected for dead time, drift and accumulated using ImageJ software ${ }^{59}$ in combination with the Open-MIMS plugin ${ }^{60}$.

References

1. Kilian, R. et al. Millennium-scale volcanic impact on a pristine and superhumid ecosystem. Geology 34 (8), 609-612 (2006).

2. Loisel, J. \& Bunsen, M. Abrupt fen-bog transition across Southern Patagonia: Timing, causes and impacts on carbon sequestration. Front. Ecol. Evol. 8, 273; 10.3389/fevo.2020.00273 (2020).

3. Fontjin, K. et al. Late Quaternary tephrostratigraphy of southern Chile and Argentina. Quat. Sci. Rev. 89, 70-84 (2014).

4. Lowe, D. Tephrochronology and its application: A review. Quat. Geochron. 6(2), 107-153 (2011).

5. Smith, R. E. et al. Refining the Late Quaternary tephrochronology for southern South America using the Laguna Potrok Aike sedimentary record. Quat. Sci. Rev. 218, 137-156 (2019).

6. Stern, C. R. Active Andean volcanism: Its geologic and tectonic setting. Rev. Geol. Chile 31(2), 161-206 (2004). 
7. Stern, C. R. Holocene tephrochronology record of large explosive eruptions in the southernmost Patagonian Andes. Bull. Volcan. 70(4), 435-454 (2008).

8. Del Carlo, P. et al. Late Glacial-Holocene tephra from southern Patagonia and Tierra del Fuego (Argentina, Chile): A complete textural and geochemical fingerprinting for distal correlations in the Southern Hemisphere. Quat. Sc. Rev. 195,153-170 (2018).

9. Kilian, R. \& Lamy, F. A review of Glacial and Holocene paleoclimate records from

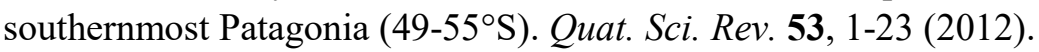

10. Yu, S.-Y., Shen, J., Colman, S. M. Modeling the radiocarbon reservoir effect in lacustrine systems. Radiocarbon 49, 1241-1254 (2007).

11. Bertrand, S., Hughen, K. A., Sepulveda, J. and Pontaja, S. Geochemistry of surface sediments from the fjords of Northern Chilean Patagonia $\left(44-47^{\circ} \mathrm{S}\right)$ : Spatial variability and implications for paleoclimate reconstructions. Geochim. Cosmochim. Acta 76, 125-146 (2012).

12. Biester, H. et al. Elevated mercury concentrations in a peat bog of the Magellanic Moorlands, Chile $\left(53^{\circ} \mathrm{S}\right)$ - an anthropogenic signal? Earth Planet. Sci. Lett. 201, 609-620 (2002).

13. Kilian, R. et al. Holocene peat and lake sediment tephra record from the southernmost Andes (53-55 S). Rev. Geol. Chile 30, 47-64 (2003).

14. Martini, I. P., Martínez-Cortizas, A., Chesworth, W. (ed.) Peatlands: Evolution and records of environmental and climate changes. Developments in Earth Surface Processes 9 (Elsevier, Amsterdam, 2006).

15. Jones, M. T. \& Gislason, S. R. Rapid release of metal salts and nutrients following the deposition of volcanic ash into aqueous environments. Geochim. Cosmochim. Acta 72, 3661-3680 (2008).

16. Opfergeld, S. et al. Iron and silicon isotope behavior accompanying weathering in Icelandic soils, and the implications for iron export from peatlands. Geochim. Cosmochim. Acta 217, 273-291 (2017).

17. Pearce, N. J. G., Alloway, B. V., Wickham, C. Correlating weathered, microphenocrystrich, intermediate tephra: An approach combining bulk and single shard analyses from the Lepue Tephra, Chile and Argentina. Quat. Int. 500, 71-82 (2019).

18. Frisia, S., Borsato, A., Susini, J. Synchrotron radiation applications to past volcanism archived in speleothems: An overview. J. Vol. Geo. Res. 177, 96-100 (2008)

19. Frisia, S. et al. The influence of Antarctic subglacial volcanism on the global iron cycle during the Last Glacial Maximum. Nat. Commun. 8, 15425; 10.1038/ncomms15425 (2017).

20. Siklósy, Z. et al. Bronze Age volcanic event recorded in stalagmites by combined isotope and trace element studies. Rapid Comm. Mass Spectrom. 23, 801-808 (2009).

21. Badertscher, S. et al. Speleothems as sensitive recorders of volcanic eruptions - the Bronze Age Minoan eruption recorded in a stalagmite from Turkey. Earth Planet. Sci. Lett. 392, 58-66 (2014).

22. Jamieson, R. A., Baldini, J. U. L., Frappier, A. B., Müller, W. Volcanic ash fall events identified using principal component analysis of a high-resolution speleothem trace element dataset. Earth Planet. Sci. Lett. 426, 36-45 (2015).

23. Frisia, S., Borsato, A., Fairchild, I. J., Susini, J. Variations in atmospheric sulphate recorded in stalagmites by synchrotron micro-XRF and XANES analyses. Earth Planet. Sci. Lett. 235, 729-740 (2005).

24. Schimpf, D. et al. The significance of chemical, isotopic, and detrital components in three coeval stalagmites from the superhumid southernmost Andes $\left(53^{\circ} \mathrm{S}\right)$ as high-resolution palaeo-climate proxies. Quat. Sci. Rev. 30(3-4), 443-459 (2011).

25. Klaes, B. et al. Middle to Late Holocene mobilization of DOC-bound $\mathrm{Pb}$ and $\mathrm{Y}$ in the Magellanic moorlands (Chile, $53^{\circ} \mathrm{S}$ ) as a function of sea spray fertilization, climate variations and volcanic fallout? A preliminary report. E\&G Quat. Sci. J. 67, 1-6 (2018). 
26. Lamy, F. et al. Holocene changes in the position and intensity of the southern westerly wind belt. Nat. Geosci. 3(10), 695-699 (2010).

27. Garreaud, R., Lopez, P., Minvielle, M., Rojas, M. Large-Scale Control on the Patagonian Climate. J. Climate 26(1), 215-230 (2013).

28. Weidemann, S. et al. A 17 year record of meteorological observations across the Gran Campo Nevado Ice Cap in Southernmost Patagonia. Frontiers Earth Sci. 6(53); 10.3389/feart.2018.00053 (2018).

29. Scholz, D. \& Hoffmann, D. L. StalAge - An algorithm designed for construction of speleothem age models. Quat. Geochron. 6, 369-382. (2011).

30. Budsky, A. et al. Speleothem record suggests enhanced summer drought in south-eastern Spain between 9.7 and $7.5 \mathrm{ka}$ - a circum-Western Mediterranean anomaly? The Holocene 29, 1113-1133 (2019).

31. Stern, C. R. \& Kilian, R. Role of the subducted slab, mantle wedge and continental crust in the generation of adakites from the Andean Austral Volcanic Zone. Contrib. Min. Petr. 123, 263-281 (1996).

32. Orland, I. J. et al. Seasonal climate signals (1990-2008) in a modern Soreq Cave stalagmite as revealed by high-resolution geochemical analysis. Chem. Geo. 363, 322-333 (2014).

33. Ayris, P. M. \& Delmelle, P. The immediate environmental effects of tephra emission. Bull. Volcan. 74, 1905-1936 (2012).

34. Mohr, C. H., Korup, O., Ulloa, H., \& Iroumé, A. Pyroclastic eruption boosts organic carbon fluxes into Patagonian fjords. Glob. Biogeochem. Cycl. 31, 1626-1638 (2017).

35. Möckel, S., Erlendsson, E., Prater, I., Gísladóttir, G. Tephra deposits and carbon dynamics in peatlands of a volcanic region: Lessons from the Hekla 4 eruption. Land Degrad. Dev. 32, 654-669 (2020).

36. Hughes, P. D. M. et al. The impact of high tephra loading on late-Holocene carbon accumulation and vegetation succession in peatland ecosystems. Quat. Sci. Rev. 67, 160175 (2013).

37. Mergelov, N. et al. Alteration of rocks by endolithic organisms is one of the pathways for the beginning of soils on Earth. Nature Sci. Rep. 8, 3367; 10.1038/s41598-018-21682-6 (2018).

38. Takahashi, T. \& Dahlgren, R. A. Nature, properties and function of aluminum-humus complexes in volcanic soils. Geoderma 263, 110-121 (2016).

39. Bonatotzky, T., Ottner, F., Erlendsson, E., Gísladóttir, G. The weathering of volcanic tephra and how they impact histosol development. An example from South East Iceland. Catena 172, 634-646 (2019).

40. Mueller, C. W. et al. Advances in the analysis of biogeochemical interfaces, NanoSIMS to investigate soil microenvironments. Adv. Agron. 121, 1-46 (2013).

41. Novák, M., Adamová, M., Kelman Wieder, R., Bottrell, S. H. Sulfur mobility in peat. Appl. Geochem. 20, 673-681 (2005).

42. Worrall, F. et al. The total phosphorus budget of a peat-covered catchment. J. Geophys. Res.: Biogeosci. 121, 1814-1828 (2016).

43. Wynn, P. M. et al. Biogeochemical cycling of sulphur in karst and transfer into speleothem archives at Grotta di Ernesto, Italy. Biogeochemistry 114, 255-267 (2013).

44. Li, X. et al. A 9000-year carbon isotopic record of acid-soluble organic matter in a stalagmite from Heshang Cave, central China: Paleoclimate implications. Chem. Geo. $\mathbf{3 8 8}$, 71-77 (2014).

45. Blyth, J. A., Hartland, A., Baker, A. Organic proxies in speleothems - New developments, advantages and limitations. Quat. Sci. Rev. 149, 1-7 (2016).

46. Dieleman, C. M. et al. Climate change effects on peatland decomposition and porewater dissolved organic carbon biogeochemistry. Biogeochemistry 128, 385-396 (2016). 
47. Tank, S. E., Striegl, R. G., McClellad, J. W., Kokelj, S. V. Multi-decadal increases in dissolved organic carbon and alkalinity flux from the Mackenzie drainage basin to the Arctic Ocean. Environ. Res. Lett. 11(5), 054015; 10.1088/1748-9326/11/5/054015 (2016).

48. Broder, T., Blodau, C., Biester, H., Knorr K. H. Sea spray, trace elements, and decomposition patterns as possible constraints on the evolution of $\mathrm{CH}_{4}$ and $\mathrm{CO}_{2}$ concentrations and isotopic signatures in oceanic ombrotrophic bogs. Biogeochemistry 122, 327-342 (2015).

49. Mathijssen, P. J. H., Galka, M., Borken, W., Knorr, K.-H. Plant communities control long term carbon accumulation and biogeochemical gradients in a Patagonian bog. Sci. Tot. Environ. 684, 670-681 (2019).

50. Borsato, A., Frisia, S., Fairchild, I. J., Somogyi, A., Susini, J. Trace element distribution in annual stalagmite laminae mapped by micrometer-resolution X-ray fluorescence: Implications for incorporation of environmentally significant species. Geochim. Cosmochim. Acta 71, 1494-1512 (2007).

51. Breuer, S. et al. Holocene denudation rates from the super-humid southernmost Patagonian Andes $\left(53^{\circ} \mathrm{S}\right)$ deduced from lake sediment budgets. Geomorphology 187, 135-152. (2013).

52. Sigl, M. et al. Timing and climate forcing of volcanic eruptions for the past 2,500 years. Nature 523, 543-549 (2015).

53. Richards, D. A. \& Dorale, J. A. Uranium-series chronology and environmental applications of speleothems. Rev. Mineral. Geochem. 52(1), 407-460 (2003).

54. Wedepohl, K. H. The composition of the continental crust. Geochim. Cosmochim. Acta 59, 1217-1232 (1995).

55. R Core Team. The R Project for statistical computing. https://www.r-project.org (2020).

56. Pacton, $M$. et al. Going nano: A new step toward understanding the processes governing freshwater ooid formation. Geology 40(6), (2012).

57. Hoppe, P., Cohen, S., Meibom, A. NanoSIMS: Technical aspects and applications in cosmochemistry and biological geochemistry. Geostand. Geoanalytical Res. 37(2), 111-154 (2013).

58. Perkins, A. M. Observations under electron microscopy of magnetic minerals extracted from speleothems. Earth Planet. Sci. Lett. 139, 281-289 (1996).

59. Rasband, W. National Institutes of Health (NIH) of the United States of America. ImageJ Image processing and analysis in java. https://imagej.nih.gov/ij (2020)

60. OpenMIMS from the National Resource for Imaging Mass Spectrometry (NRIMS). An ImageJ plugin for MIMS image analysis. https://github.com/BWHCNI/OpenMIMS (2020)

61. GeoMapApp from the Marine Geoscience Data System (MGDS) at Lamont-Doherty Earth Observatory of Columbia University. http://www.geomapapp.org (2020)

\section{Data availability}

The authors declare that the data supporting the findings of this work are included in the article and its Supplementary Information file. The LA-ICP-MS dataset analyzed during the current study is available in the PANGAEA data repository (https://doi.org/10.1594/PANGAEA/...). NanoSIMS and SEM data are available from the corresponding author on reasonable request. 


\section{Acknowledgements}

609 Andreas Kronz (GZG), Johann Lugmeier and Gertraud Harrington (TUM) are acknowledged for 610 technical assistance and analytical support. This work was funded by grants AR 367/4, Ki 456/10-11, 611 KR 2061/1, MA 821/32 and Wo 362/18 of the German Research Foundation (DFG).

\section{Author contributions}

613 B.K. conceptualized this work together with R.K. and G.W., planned the NanoSIMS operations, 614 compiled the data and performed the analyses. K.K. and K.S. provided the LA-ICP-MS analyses. 615 NanoSIMS operations were enabled by C.W.M. and executed by C.M. D.Scho. established the refined 616 chronology. Statistical analyses were performed by J.S. D.Schi. dated the MA1 stalagmite and ensured 617 data consistency. R.K., G.W., S.T.-B. and H.W.A. shared supervision. B.K. wrote the manuscript, jointly 618 with G.W. All authors contributed to the final version. R.K. acquired the funding, coordinated the field 619 work, and was the driving force behind our research in Patagonia. His enthusiasm and contagious 620 curiosity for a deeper understanding of this remote ecosystem will never be forgotten.

\section{Conflict of interest}

622 The authors declare no competing interest. 
Fig. 1:

Location of the study area and site characteristics. a, The study site at the windward side of the southernmost Andes, $\sim 40 \mathrm{~km} \mathrm{~S}$ of the Mt. Burney volcano. Inserted isopach lines indicate the thickness and distribution of tephra deposits from the $\mathrm{MB}_{2}$ eruption ${ }^{7}$. In addition, Reclus and Aguilera volcanoes are shown. b, Marcelo Arévalo (MA) cave and its environmental context. The hydrological connection between the cave and its catchment is schematically illustrated. The background map in a was generated with GeoMapApp ${ }^{61}$.

Fig. 2:

New age-depth model of the MA1 stalagmite. a, StalAge ${ }^{29}$ age-depth model, including the corresponding 95\% confidence limits (thin red lines). Uncorrected ages and ages after detrituscorrection $^{30}$ are shown with standard deviations as $2 \sigma$-error bars (see Table S1 for details). b. Photo of MA1 including the 18 sampling points for ${ }^{230} \mathrm{Th} / \mathrm{U}$-dating.

Fig. 3:

Stable isotope and LA-ICP-MS data of MA1 between 4.5 and $0.6 \mathrm{kyrs}$ BP. $\delta^{18} \mathrm{O}$ and $\delta^{13} \mathrm{C}$ records ${ }^{24}$ of the MA1 stalagmite combined with concentrations of S, P, U, Sr and Zr. ${ }^{14} \mathrm{C}$-ages of tephra layers from Late Holocene eruptions of volcanoes of the Southern and Austral Andean Volcanic Zone ${ }^{3}$ are indicated. Rectangles mark the two periods displayed in Fig. 4. Orange bars highlight newly dated Plinian eruptions of Mt. Burney at 4.216 and 2.291 kyrs BP, confirmed by PCA results (Figs. 6 and S1). Positions of lamina sections investigated by SEM and NanoSIMS (Figs. 7 and S2) are also shown.

Fig.4:

Stable isotope and LA-ICP-MS data of MA1 for time spans enclosing two Mt. Burney eruptions. $\delta^{18} \mathrm{O}$ and $\delta^{13} \mathrm{C}$ records ${ }^{24}$ of the MA1 stalagmite combined with concentrations of $\mathrm{S}, \mathrm{P}, \mathrm{U}, \mathrm{Sr}$ and $\mathrm{Zr}$ (a, $2.4-2.0$ kyrs BP; $\mathbf{b}, 4.3-4.0 \mathrm{kyrs}$ BP). ${ }^{14} \mathrm{C}$-ages of tephra layers from eruptions of Cerro Hudson and Mt. Burney ${ }^{3}$ are indicated. Orange bars highlight newly dated Plinian eruptions of Mt. Burney at 4.216 and 2.291 kyrs BP, confirmed by PCA results (Figs. 6 and S1). Light gray bars mark time spans characterized by an elevated incorporation of micron scale detrital volcanic glass/tephra following both eruptions. Positions of lamina sections investigated by SEM and NanoSIMS (Figs. 7 and S2) are also shown.

Fig. 5:

Variations and relationships of $\mathrm{Si}$ and $\mathrm{Zr}$ concentrations in MA1 determined by LA-ICP-MS. In the upper part, the whole record (a, 4.5 and $0.6 \mathrm{kyrs}$ BP) is shown. Rectangles in a mark the time spans displayed in $\mathbf{b}(2.4-2.0 \mathrm{kyrs}$ BP) and $\mathbf{c}(4.3-4.0 \mathrm{kyrs}$ BP). Orange bars highlight newly dated eruptions 
657 of Mt. Burney at 4.216 and 2.291 kyrs BP. The corresponding binary plots in the lower part indicate a

658 high correlation of measurements on a mixing line between speleothem carbonate $\left(\mathrm{CaCO}_{3}\right)$ and a Si-

659 /Zr-rich endmember with a Si/Zr ratio of 3300 (blue line). The most likely candidate for this $\mathrm{Si}$-/Zr-rich

660 endmember is $\mathrm{MB}_{2}$ glass ${ }^{7,8}$. Vectors pointing outwards from the mixing line towards quartz $\left(\mathrm{SiO}_{2}\right)$ and 661 zircon $\left(\mathrm{ZrSiO}_{4}\right)$ endmembers are included.

662 Fig. 6:

663 Scores of principal component PC-1 of the PCA performed on LA-ICP-MS data (S, P, U, Si, Sr 664 and Zr). a, PC-1 scores for the time span from 4.5 to $0.6 \mathrm{kyrs}$ BP. Rectangles indicate the periods 665 displayed in b (2.4 - 2.0 kyrs BP) and c (4.3 - 4.0 kyrs BP). Orange bars mark times in which PC-1 666 main spikes are synchronous with trace element peaks (Figs. 3-5; at 4.216 and $2.291 \mathrm{kyrs}$ BP).

667 Fig. 7:

668 Fine-grained glass shards and Mt. Burney phenocrysts detected in laminae of MA1, formed after 669 the two Mt. Burney eruptions at 4.216 and 2.291 kyrs BP. SEM images show a glass shard (a, 2.29 670 kyrs BP) and phenocrysts coated with residual, vesicle-rich volcanic glass (b and c, 4.15 kyrs BP) 671 incorporated in MA1. NanoSIMS secondary ion mappings of detrital components in laminae at 3.92 and $672 \quad 2.29 \mathrm{kyrs}$ BP are displayed in $\mathbf{d}$ and $\mathbf{e}$. 


\section{Figures}

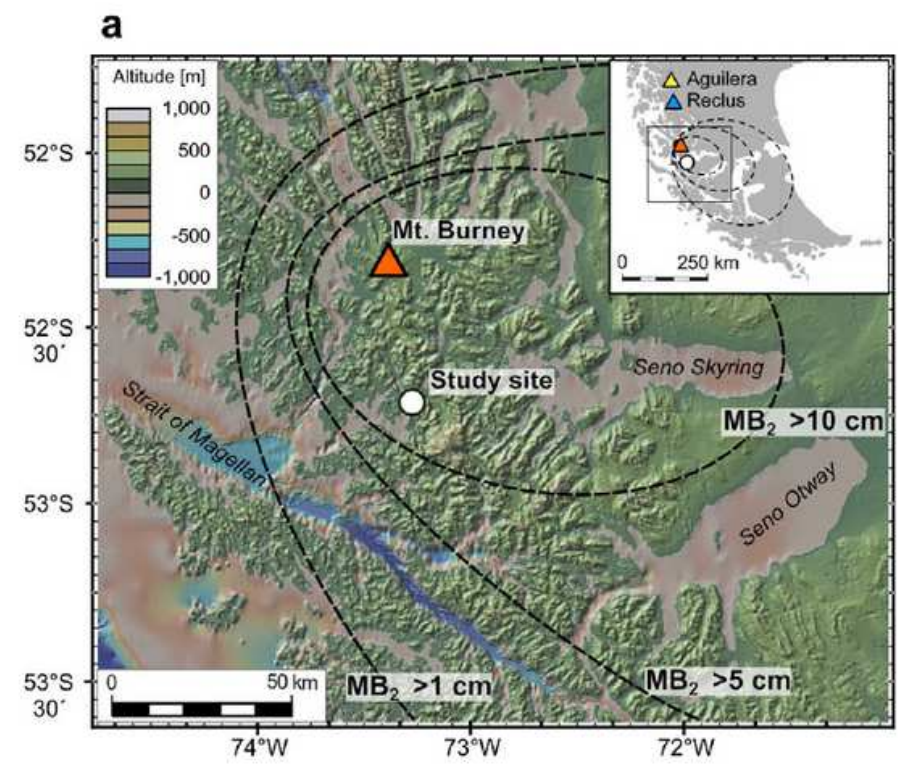

\section{b}

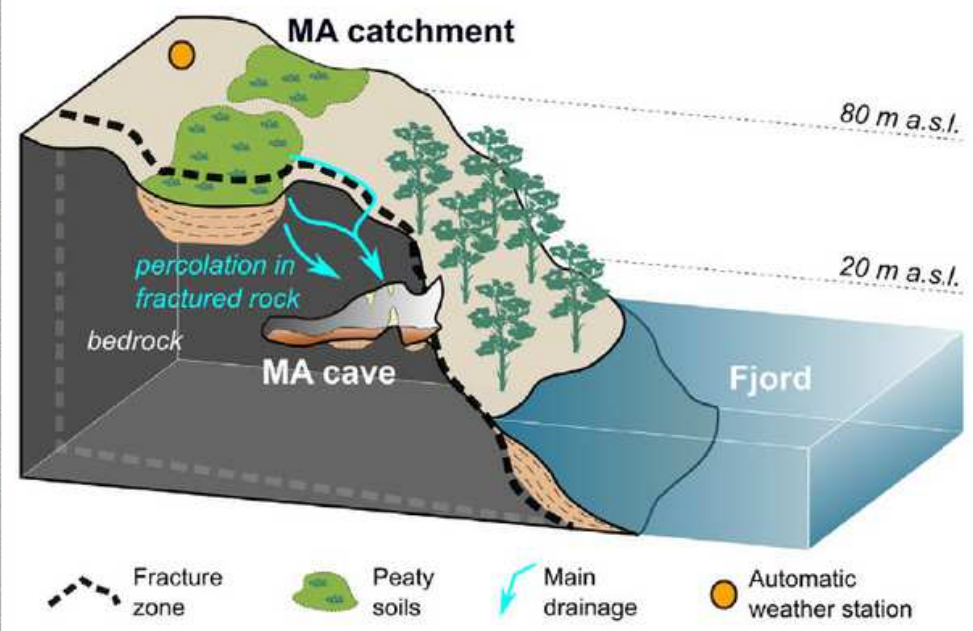

Figure 1

Location of the study area and site characteristics. a, The study site at the windward side of the southernmost Andes, $\sim 40 \mathrm{~km} \mathrm{~S}$ of the Mt. Burney volcano. Inserted isopach lines indicate the thickness and distribution of tephra deposits from the MB2 eruption7. In addition, Reclus and Aguilera volcanoes are shown. b, Marcelo Arévalo (MA) cave and its environmental context. The hydrological connection between the cave and its catchment is schematically illustrated. The background map in a was generated with GeoMapApp61. 


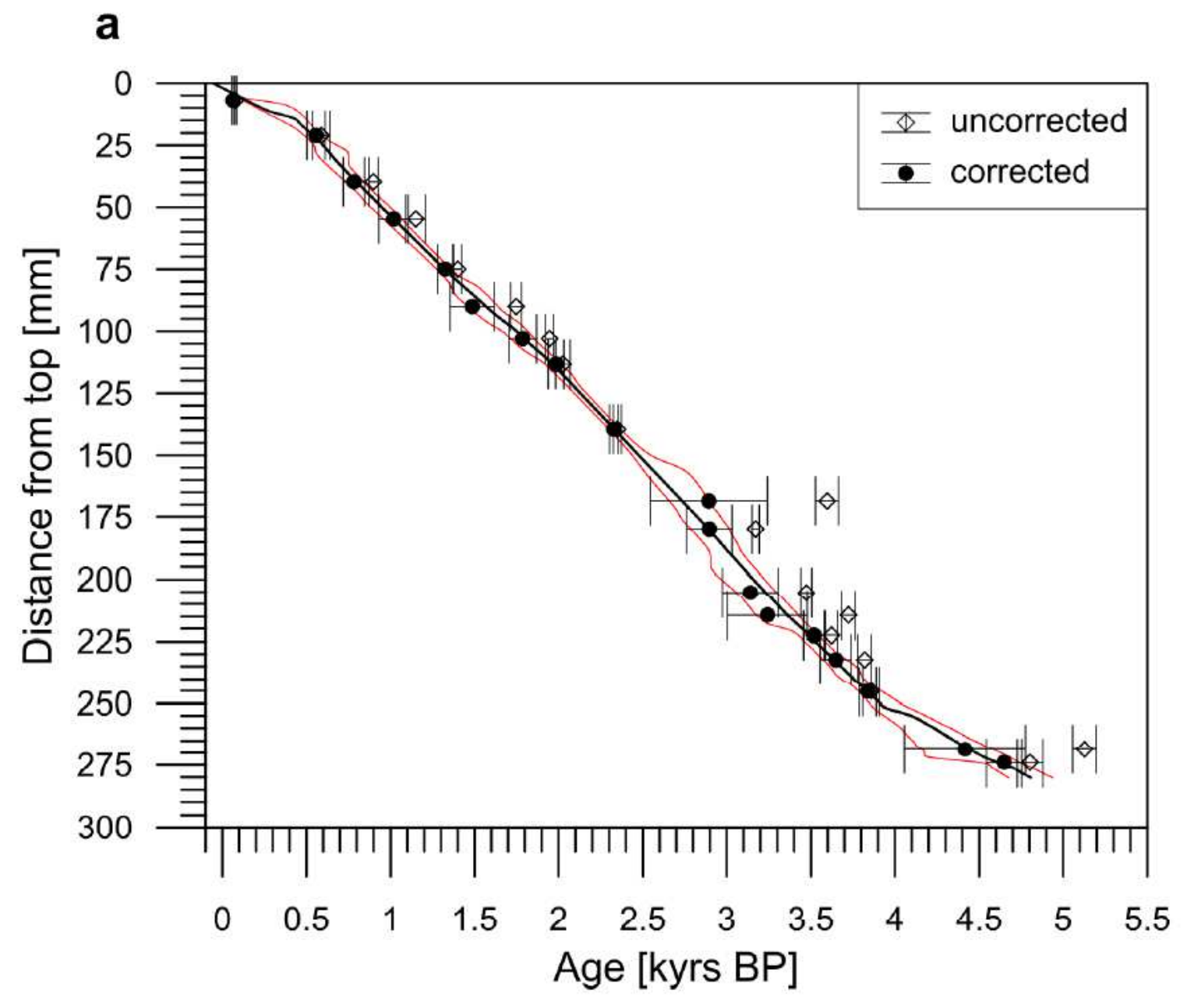

b

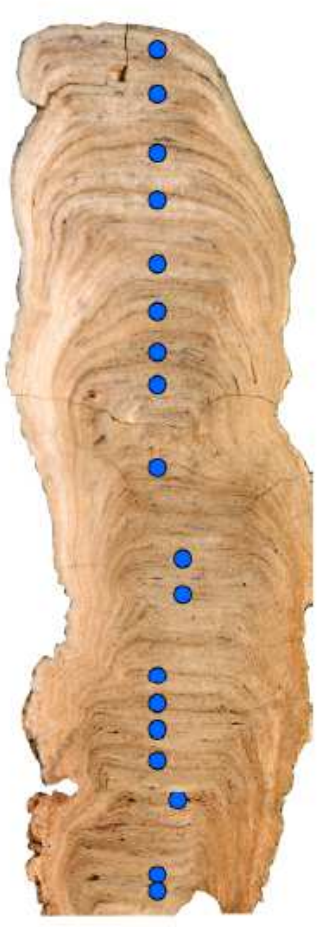

Figure 2

New age-depth model of the MA1 stalagmite. a, StalAge29 age-depth model, including the corresponding $95 \%$ confidence limits (thin red lines). Uncorrected ages and ages after detritus-correction30 are shown with standard deviations as 20 -error bars (see Table S1 for details). b, Photo of MA1 including the 18 sampling points for 230Th/U-dating. 


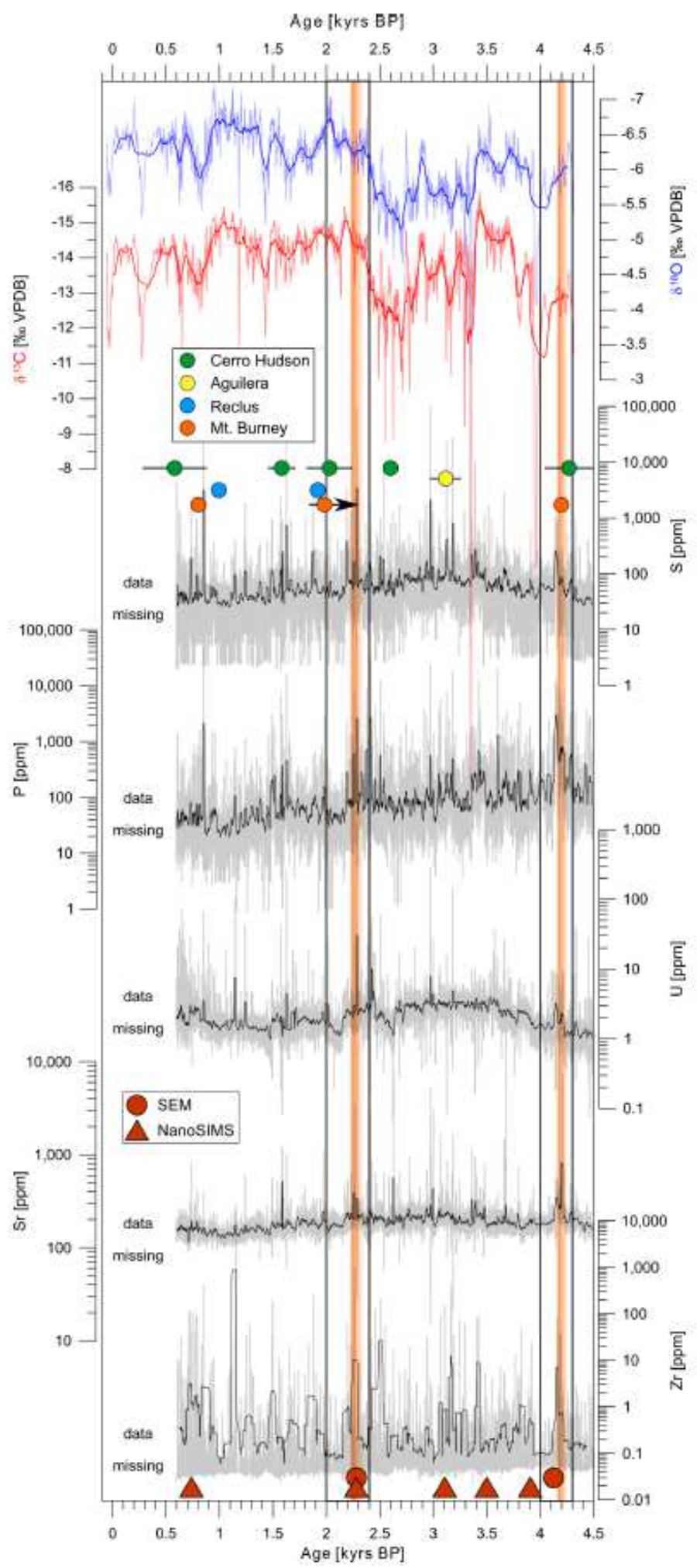

Figure 3

Stable isotope and LA-ICP-MS data of MA1 between 4.5 and $0.6 \mathrm{kyrs}$ BP. $\delta 180$ and $813 \mathrm{C}$ records 24 of the MA1 stalagmite combined with concentrations of S, P, U, Sr and Zr. 14C-ages of tephra layers from Late Holocene eruptions of volcanoes of the Southern and Austral Andean Volcanic Zone3 are indicated.

Rectangles mark the two periods displayed in Fig. 4. Orange bars highlight newly dated Plinian eruptions 
of Mt. Burney at 4.216 and 2.291 kyrs BP, confirmed by PCA results (Figs. 6 and S1). Positions of lamina sections investigated by SEM and NanoSIMS (Figs. 7 and S2) are also shown.

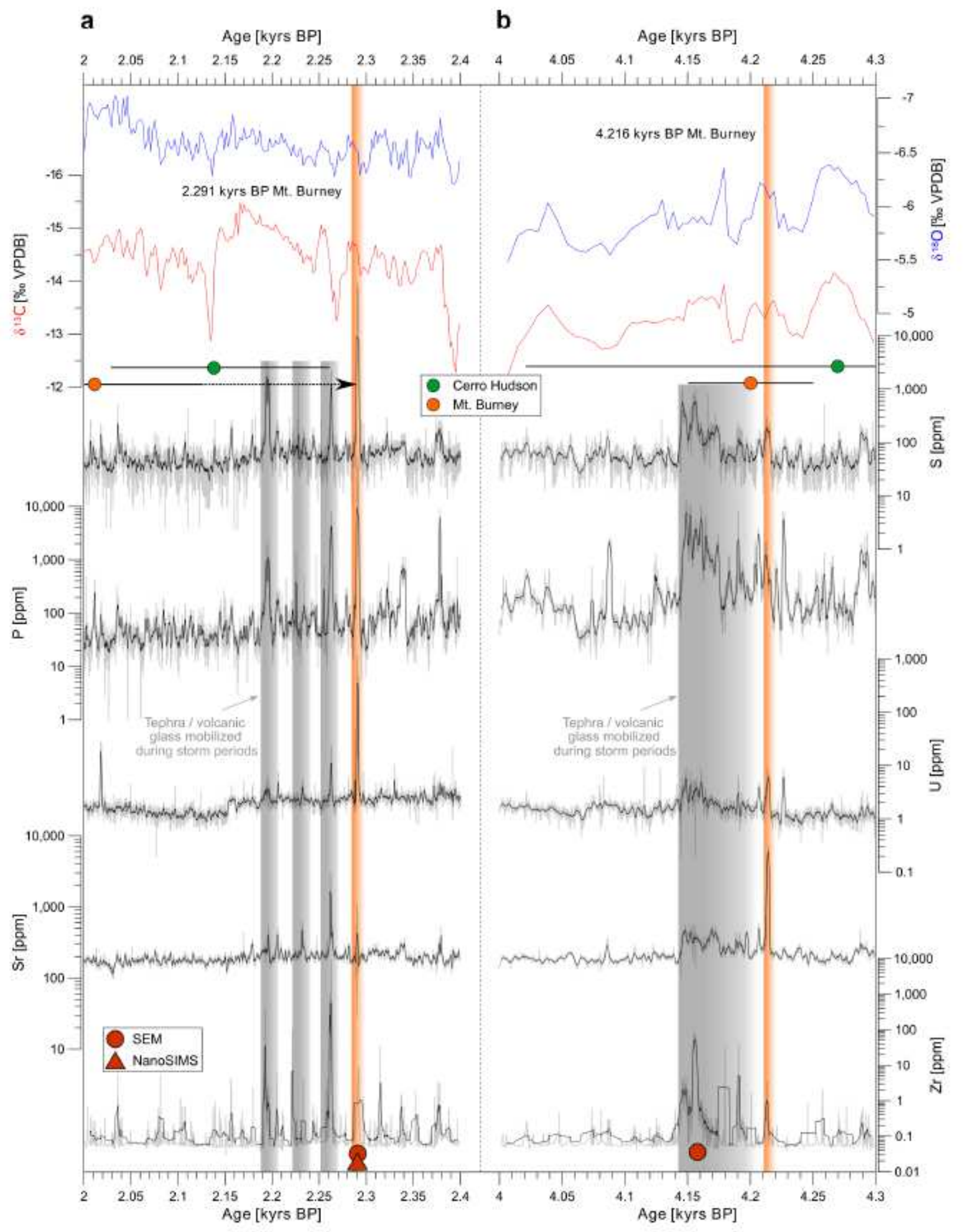

\section{Figure 4}

Stable isotope and LA-ICP-MS data of MA1 for time spans enclosing two Mt. Burney eruptions. $\delta 180$ and $\delta 13 \mathrm{C}$ records 24 of the MA1 stalagmite combined with concentrations of S, P, U, Sr and Zr (a, $2.4-2.0$ kyrs BP; b, 4.3 - 4.0 kyrs BP). 14C-ages of tephra layers from eruptions of Cerro Hudson and Mt. Burney3 
are indicated. Orange bars highlight newly dated Plinian eruptions of Mt. Burney at 4.216 and 2.291 kyrs BP, confirmed by PCA results (Figs. 6 and S1). Light gray bars mark time spans characterized by an elevated incorporation of micron scale detrital volcanic glass/tephra following both eruptions. Positions of lamina sections investigated by SEM and NanoSIMS (Figs. 7 and S2) are also shown.
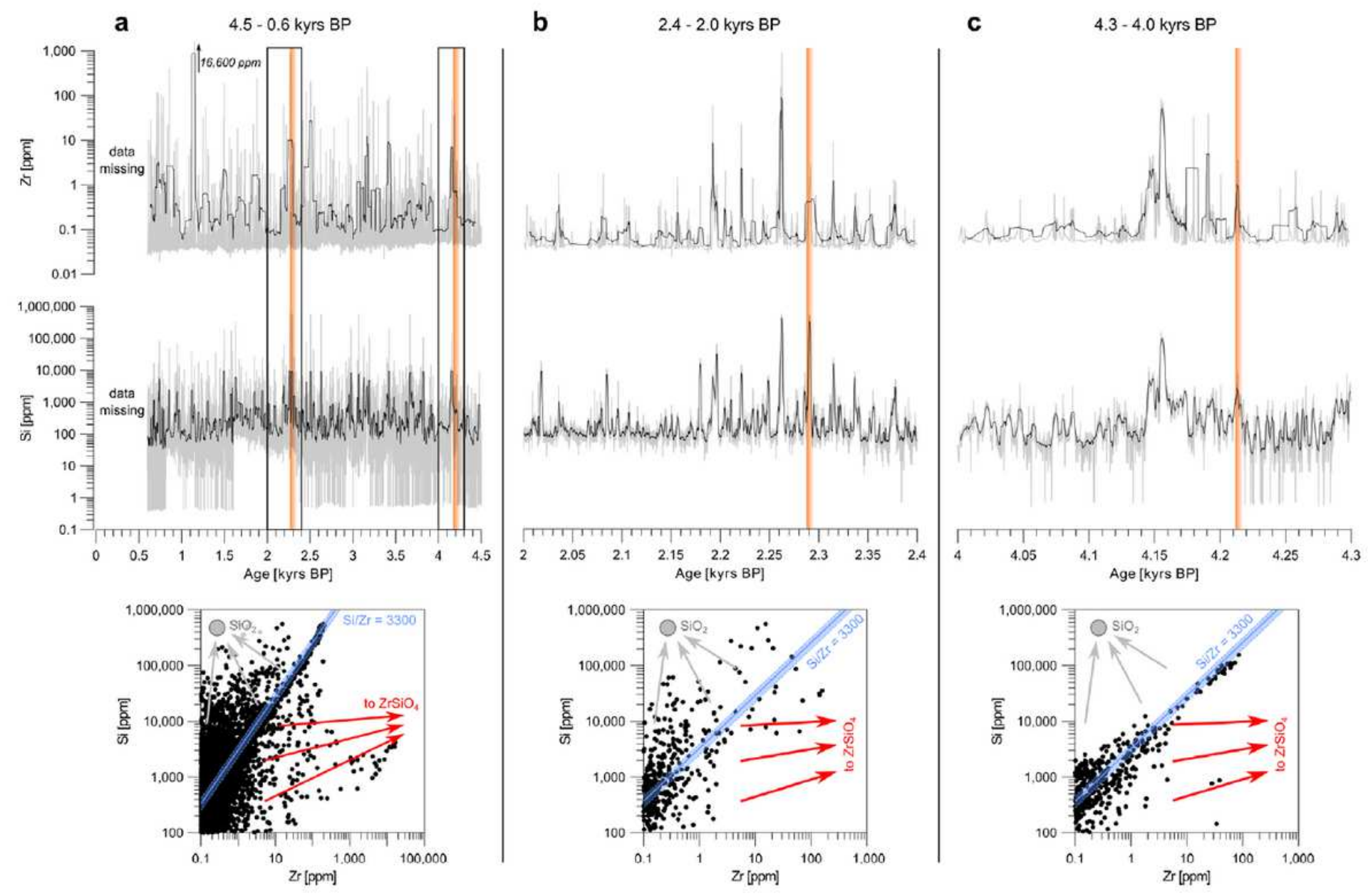

\section{Figure 5}

Variations and relationships of $\mathrm{Si}$ and $\mathrm{Zr}$ concentrations in MA1 determined by LA-ICP-MS. In the upper part, the whole record ( $\mathrm{a}, 4.5$ and $0.6 \mathrm{kyrs} \mathrm{BP})$ is shown. Rectangles in a mark the time spans displayed in b (2.4 - 2.0 kyrs BP) and c (4.3 - 4.0 kyrs BP). Orange bars highlight newly dated eruptions of Mt. Burney at 4.216 and $2.291 \mathrm{kyrs}$ BP. The corresponding binary plots in the lower part indicate a high correlation of measurements on a mixing line between speleothem carbonate ( $\mathrm{CaCO}$ ) and a Si-/Zr-rich endmember with a Si/Zr ratio of 3300 (blue line). The most likely candidate for this Si-/Zr-rich endmember is MB2 glass7,8. Vectors pointing outwards from the mixing line towards quartz (SiO2) and zircon (ZrSiO4) endmembers are included. 

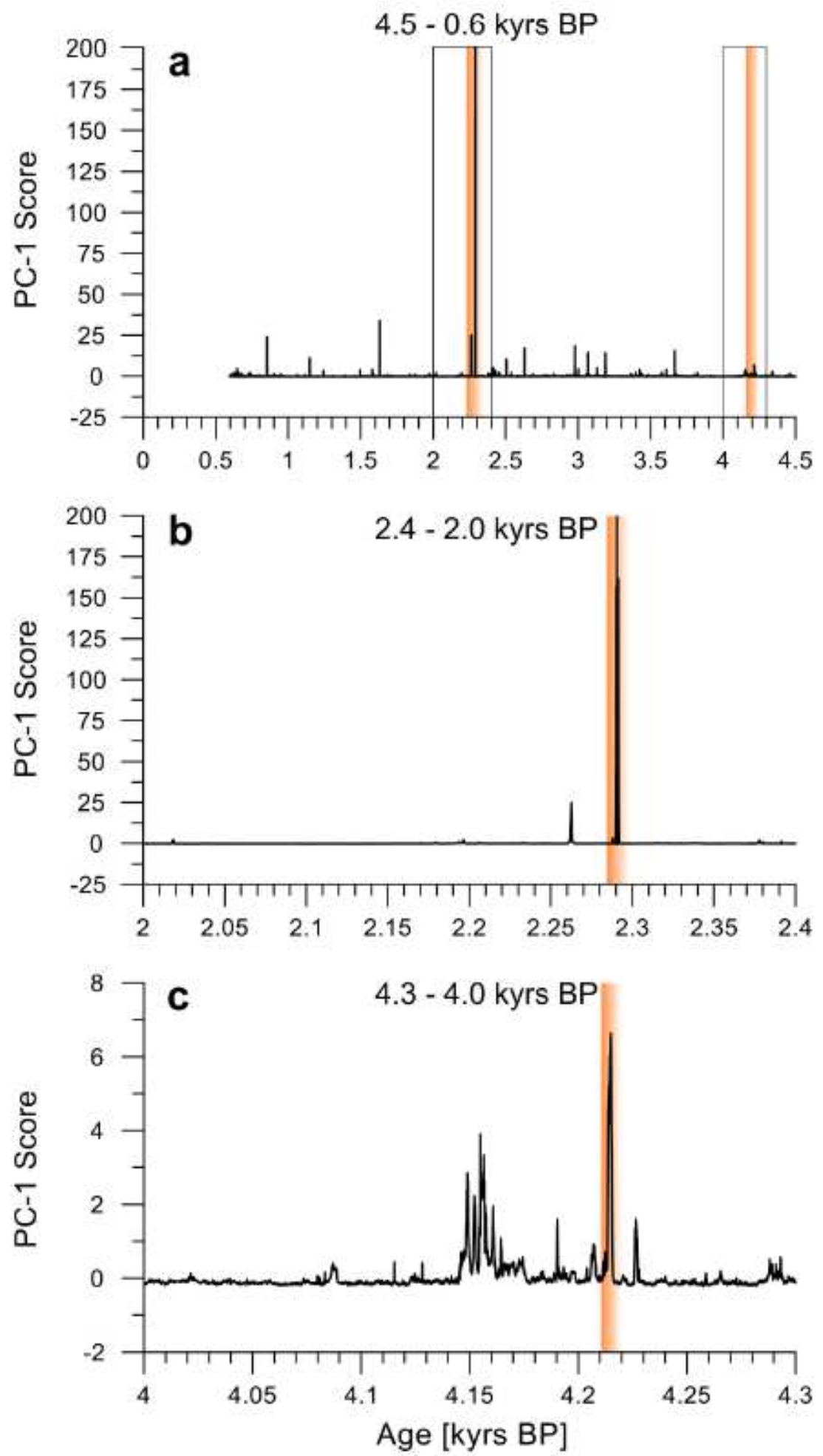

Figure 6

Scores of principal component PC-1 of the PCA performed on LA-ICP-MS data (S, P, U, Si, Sr and Zr). a, PC-1 scores for the time span from 4.5 to 0.6 kyrs BP. Rectangles indicate the periods displayed in $b$ ( 2.4 - 2.0 kyrs BP) and c (4.3 - 4.0 kyrs BP). Orange bars mark times in which PC-1 main spikes are synchronous with trace element peaks (Figs. 3-5; at 4.216 and 2.291 kyrs BP). 

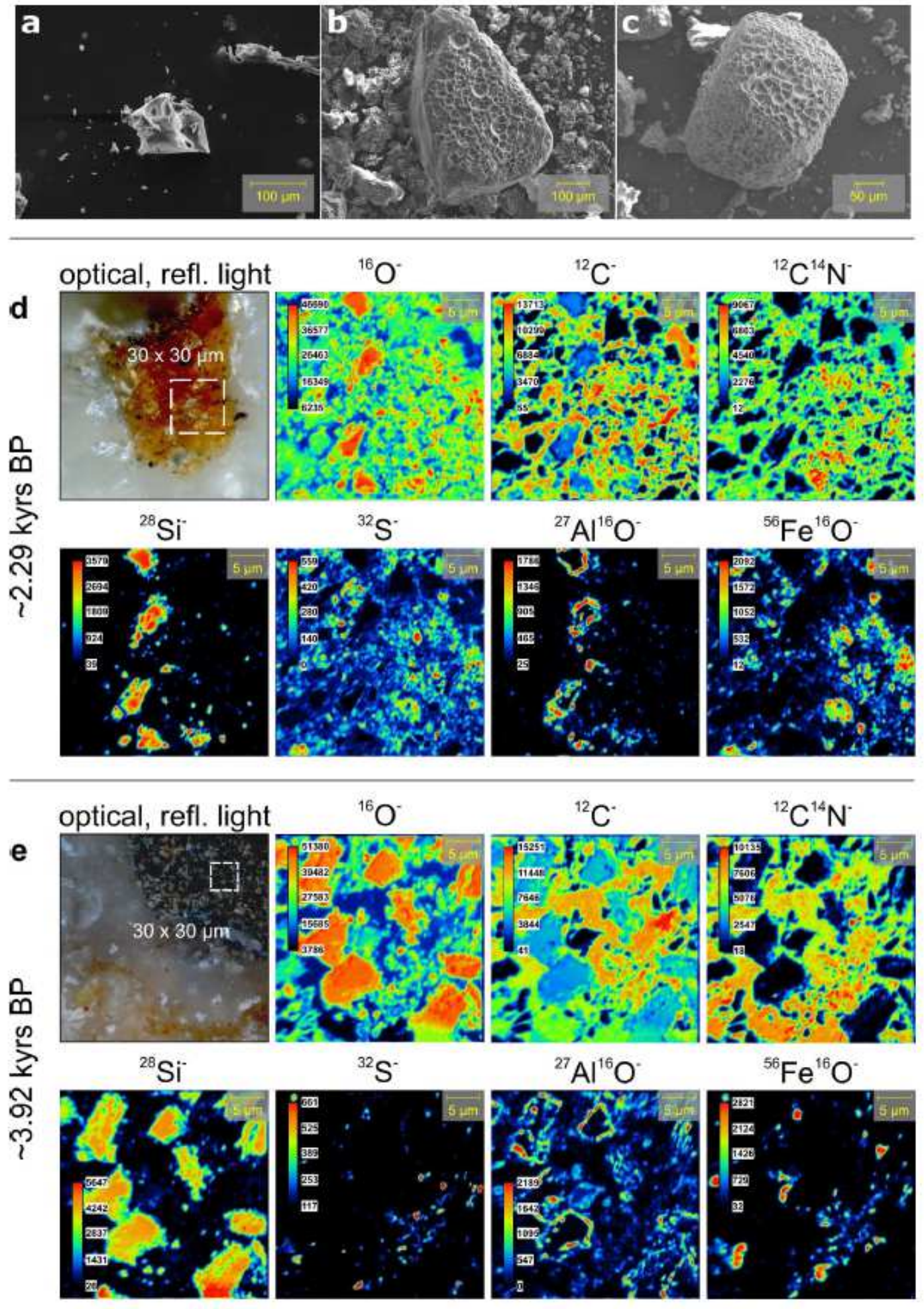

Figure 7

Fine-grained glass shards and Mt. Burney phenocrysts detected in laminae of MA1, formed after the two Mt. Burney eruptions at 4.216 and 2.291 kyrs BP. SEM images show a glass shard (a, 2.29 kyrs BP) and phenocrysts coated with residual, vesicle-rich volcanic glass (b and c, 4.15 kyrs BP) incorporated in MA1. NanoSIMS secondary ion mappings of detrital components in laminae at 3.92 and 2.29 kyrs BP are displayed in $\mathrm{d}$ and $\mathrm{e}$. 


\section{Supplementary Files}

This is a list of supplementary files associated with this preprint. Click to download.

- SupplementaryInformationKlaesetal.2021.pdf 